\title{
HALIDE EDİB ADIVAR'IN ROMANLARINDA SOSYAL BİR MESELE OLARAK DIN / İSLAM
}

\author{
RELIGION / ISLAM AS A SOCIAL ISSUE IN HALIDE EDİP \\ ADIVAR'S NOVELS
}

\section{ИСЛАМ /РЕЛИГИЯ КАК СОЦИАЛЬНЫЙ ВОПРОС В РОМАНАХ ХАЛИДЕ ЭДИБ АДЫВАРА}

\author{
Ramis KARABULUT
}

\section{ÖZ}

$\mathrm{Bu}$ çalışmada Halide Edib Adıvar (1882-1964)'ın romanlarında nasıl bir "din" anlayışı ortaya koyduğu veya toplumsal ve kültürel hayat içinde "din"e karşı nasıl bir yaklaşım içinde bulunduğu tespit edilmeye çalışılmıştır. Bilindiği gibi Türk toplumu, Tanzimat (1939)'tan sonra hemen her alanda Batılılaşma çabası içine girmiş ve bu durum günümüze kadar da devam etmiş̧tir. Bu süreç içerisinde bütün Avrupaîleşme ve modernleşme çabaları maddî ve manevî pek çok değişikliği ve tartışmaları beraberinde getirmiştir. Başta aydın kesim olmak üzere, toplumun hemen her tabakasında Doğu ile Batı'nın değerler dünyası çatışmalara sebep olmuştur. Bu çatışmaların odağı daima din-modernizm çatışması olduğu bilinen bir gerçektir. Özellikle Tanzimat'la birlikte genel olarak Batılılaşma serüvenimiz üzerine düşünen ve yazan aydınlar, modernleşme ihtiyacı ile dinî kural ve kurumlar karşısında nasıl bir tutum içinde olunması gerektiğine dair farklı yaklaşımlar ve fikirler içinde olmuşlardır. Bu süreç içinde ortaya konulan birçok edebî eserin ana teminin "Doğu - Batı" çatışması olduğu malumdur. Bir aydın ve sanatçı olarak Halide Edib Adıvar da II. Meşrutiyet ve Cumhuriyet dönemlerinde çeşitli ideolojik, toplumsal, kültürel değişim ve tartışmaların içinde eserleriyle yer alan sanatçılardandır. Halide Edib'in romanlarında, Batılılaşan ve sürekli değişen Türk toplumunda "din" millî kimliği oluşturan ve koruyan önemli bir işleve sahiptir. Ancak bu din anlayışı, her insanı kucaklayan, laik, sevgiye ve akla dayanan yönleriyle "heterodoks" anlayışa yakın duran özgün bir yorum olarak karşımıza çıkar. ADIVAR

Anahtar Kelimeler: Batılılaşma, Doğu-Batı Çatışması, din, Halide Edib

* Yrd. Doç. Dr., Niğde Ömer Halisdemir Üni. FEF Türk Dili ve Edebiyatı Öğr. Üyesi, rkarabulut611@hotmail.com

10.17498/kdeniz.349163 


\section{ABSTRACT}

In this study, we try to find out that what kind of understanding and approach towards "religion" Halide Edib Adivar (1882-1964) put forward in her novels. As known, with the Rescript of Gülhane, Turkish society went into the effort of westernization in almost all areas of life and this effort has continued until today. In this process, all attempts for westernization and modernization brought about many changes and discussions, both material and spiritual. The values of the East and the West have caused conflicts in almost every segment of the society, especially among the intellectuals. The core of these conflicts is always known to be a conflict between religion and modernism. Intellectuals who think and write about our westernization process in general, especially with the Rescript of Gülhane, have come up with different approaches and ideas about the need for modernization and the attitude towards religious rules and institutions. It is well known that the main theme of many literary works produced in this process is the "East-West" conflict. As an intellectual and artist Halide Edib Adivar is among the ones who are involved in various ideological, social, cultural changes and discussions during the Second Constitutional Period and Republican Period. In Halide Edib's novels, "religion" has an important role in forming and preserving our national identity in the period of westernization and constant change of Turkish society. However, this understanding of religion comes out as a unique interpretation that is close to the "heterodox" understanding with its secular, loving, and reasoning orientations embracing every human being.

Key Words: Westernization, East-West Conflict, Religion, Halide Edib ADIVAR

\section{АННОТАЦИЯ}

В статье попытались установить как воспринимается обшеством релингия и как относится оно к нему по романам Халиде Эдиб Адывар (18821964). Как известно, турецкое общество после Танзимата (1839) почти во всех сферах своей жизни начал европеизацию и этот процесс продолжается по сей день. Этот процесс привлёк за собой очень много перемен в материальной и духовной жизни общества и обсуждения. Во главе с с интеллигенцией во всех слоях общества начались конфликты по поводу западных и восточных ценностей. Оно стало фокусроватся на конфликт между религией и млдернизмом. Наряду с танзиматом турецкие деятели, которые думали и писали о насаждении в нашем обществе западных норм и идеалов, высказывали своё мнение о нуждах в модернизации и в процессе этого о позициях религиозных правил и институтов. Известно, что основной темой многих литературных произведений, созданных в теченнии этого процесса, является противостояние между востоком и Западом. Халиде Эдиб Адывар, как интеллектуал и исскуствовед эпохи второй конституции и республиканского периода, своими произведениями участвовал в различных идеологических, социальных, культурных изменениях и дискуссиях. В 
романах Халиде Эдиба, постоянно меняющемся и стоящем на пути насаждении западных норм и идеалов и турецком обществе, религия имеет важную функцию, которая составляет и защищает национальную идентичность. Однако, такое понимание религии является как уникальная интерпретация, близкая к «неортодоксальному» пониманию с его светскими, любящими и рассудительными ориентациями, охватывающий каждого индивида.

Ключевые слова: насаждение западных норм и идеалорелигия, в, конфликт между западом и востоком, Халиде Эдиб Адывар.

\section{Giriş}

18. Yüzyıl'da gerileme ve sonraki yüzyılda dağılma dönemine giren Osmanlı İmparatorluğu, devam eden çöküşü engellemek için yüzünü Batı'ya çevirerek birtakım yenilik faaliyetlerine girişmiştir. Başta askerî ve ekonomik alanlarda görülen bu faaliyetler ilerleyen dönemde, özellikle Batı'nın üstünlüğünün resmen kabul edildiği ve medeniyet değişimi anlamına gelen Tanzimat Fermanı (3 Kasım 1839) ile önce devlet yapısına, sonra siyasî ve sosyal hayata sıçrayarak kültür hayatımızı derinden etkilemiştir. Batılılaşmanın resmî başlangıcı kabul edilen Tanzimat'tan sonra I. ve II. Meşrutiyet, I. Dünya Savaşı, Kurtuluş Savaşı, Türkiye Cumhuriyeti'nin kurulması, inkılâplar, II. Dünya Savaşı, çok partili hayata geçiş gibi önemli siyasî ve sosyal vakalar Türk toplumunda büyük değişimler yaratmıştır. Tüm bu olaylara sebep - sonuç ilişkisi kurarak yüzeysel bir dikkatle bakıldığında bile yaşanan olaylar ve değişimlerin başta Türk aydınında olmak üzere toplumun genelinde bir değerler çatışmasına yol açtığı görülür. Bu değerler çatışmasından toplumsal bir kurum olan "din” de nasibini almıştır. Bu bakımdan Türkiye'nin Tanzimat'la başlayan Batılılaşma serüveni üzerine kafa yoran ve yazılarıyla fikirlerini beyan eden pek çok Türk aydını ve sanatçısı "din” meselesi için de çeşitli fikirler ortaya atmıştır. Bunlar arasında Halide Edib, romanlarında genel anlamda Doğu - Batı çatışması yaşayan Türk toplumunun panaromasını, özelde ise bazı romanlarında daha çok inkılâplar etrafında din meselesini gündeme getirmiştir.

Doğu'nun ve Batı'nın değerler dünyasına vakıf olan Halide Edib, ülke sorunlarıyla yakından ilgilenmiş ve bu sorunları romanlarında kendi kültür birikimi ve dünya görüşüne göre yorumlamıştır. Otobiyografik izler taşıyan kimi romanlarında, yarattığı ideal kadın tipleriyle tanınan yazarımızın, ilk romanlarından itibaren gittikçe toplumsal meselelere eğildiği görülür. Bu bakımdan "Halide Edib, Batılılaşmanın yanlış anlaşılması, eğitim, din, devlet yönetimi; savaş yıllarında, yeni yönetime geçişlerde görülen ahlâk çöküntüsü, aile yapısındaki sarsıntılar gibi, yaşadı̆̆ı, gözlemlediği, ilgilendiği sorunları, romanlarında okuyucularına duyurmuştur (Önertoy, 2011: 38)."

Türk tarihinin önemli dönemeçlerinde çeşitli görevler yapmakla birlikte toplumu iyi gözlemleyen, dün ve bugün perspektifine sahip olan Halide Edib'in "devir romanları" olarak okunabilecek romanlarında "din” meselesi, değindiği 
toplumsal meseleler arasında önemli bir yere sahiptir. Onun, din meselesini çeşitli romanlarında gündeme getirip ele almasındaki temel sebep belki de kendi hayatıdır. "Çok küçük yaşta annesini kaybeden Halide Edib, babasının arka arkaya birkaç kadinla birden evlenmesi dolaylsiyla, hem babasinin hem de anneannesinin evinde yaşamak zorunda kalmıştır (Enginün, 2007:29).” Bu durum yazarın, kendisini idrak etmeye başladığ1 dönemde Batı ve Doğu'yu eşzamanlı görüp öğrenmesine ve sindirmesine sebep olur. Çünkü, bu iki ev arasında gelgitler yaşayan yazar, babasının evinde İngiliz, anneannesinin evinde ise Müslüman bir Türk'ün terbiyesini almaya başlamışıı. Bu iki farklı tesir, ilerleyen yıllarda da devam eder. Amerikan Kız Koleji yıllarından sonra gerek savaş yılları gerekse de Avrupa'da bulunduğu dönemlerde Batı dünyasını idrak etmekle birlikte, içinden çıktığ milletin değerler sistemini de yaşayarak öğrenmiş ve düşünce dünyasında bir senteze ulaşmaya çalışmıştır. Romanlarında rahatlıkla görebildiğimiz bu sentezde Halide Edib, yakından tanıdığı maddeci Batı'ın olduğu gibi taklit edilmesine karşı1ır. Gençlik döneminde hayran olduğu Batı'ın Millî Mücadele Dönemi'nde (1919-1922) masum olmadığını gördüğü için, Türk toplumunun değerlerini ihmal etmeden değişmeyi daha doğru bulur. Bu yönüyle Halide Edib'in iki farklı dünyayı gördükten sonra ulaştığı sentezde, geleneklerine bağlı hatta yer yer muhafazakâr olduğunu ve sahip çıkmamız gereken değerlerimizin başına "din”i koyduğunu, ancak bu dinin tüm insanlığı kucaklayan bir sevgiye, müsamahaya dayandığını söyleyebiliriz. Ancak bu din anlayışı sadece bir inanç sistemi olarak değil, aynı zamanda yerliliğin ve millîliğin de önemli bir unsuru olarak ele alınır. Nitekim yazarın bu özelliği, romanlarında kendisini gösterir. Bu sebeple, Halide Edib'in roman kişileri üzerinden ele aldığ 1 "din meselesi" (İslam) bu çalışmada, kronolojik sıra bozulmadan incelenmiştir: ${ }^{1}$

\section{Raik'in Annesi (1908): İdeal Müslüman Türk Kadını}

Eser, Siret'in ahlâkını giyimi kadar kötü bulduğu Necibe ile evlenmesi söz konusu olunca Heybeliada'ya kaçması ve orada Rauf Bey'le mutsuz bir evlilik hayatı geçiren Refika'ya karşı duyduğu aşkın anlatıldığı bir romadır. Siret, eserin kahraman anlatıcısıdır. O, kadınlar arasında Fransız taklitçiliğinin yaygın olduğu bir dönemde millî değerlere sahip, taklitten uzak olan Müslüman Türk kadınını arzular. Romanın daha ilk sayfalarında Çamlimanı'na doğru yürüyüş yaparken gördüğü Fransız taklitçisi kadınlar Siret'te tiksinti uyandırır. Onlardan hareketle nasıl bir kadın istediğini şöyle bir iç konuşmayla anlatır:

"Bakınız ben nasıl bir kadın isterim. Dil isterse bilsin, hattâ iki, üç; fakat hiçbir zaman Beyoğlu'nda Fransızca pazarlık etmesin. Fransız kadınlarını taklit edeceğim, diye sahte gülüşler, garip el oğuşturmaları, baş sallamaları, sıçrayarak, hoplayarak yürümeler yapmasin. Her lüzumsuz şeye Fransizca hayret etmesin. Babasını görünce "oh! mon diyö" demesin, Tanrl'ya inansın, arasira camiye gitsin. Bizim yüksek, kül renkli, loş kubbelerde inleyerek sesi yansıtan yakarışların, göz

${ }^{1} \mathrm{Bu}$ çalışmada yazarın romanlarındaki din anlayışı sadece İslam dini açısından ele alınmıştır. Romanlarında rastlanılan diğer din ve inançlarla ilgili yaklaşımlar üzerinde durulmamıştır. 
kamaştırıcı bir düzenle, o kubbe altında yere sürünen alınların çıkardı̆̆ sesin şïr ve ululuğunu ruhça duyabilecek, bu ulu ibadetin iç korkusu ile ruhu titreyen bir kadın, sonra bütün bu duygularını çocuklarına aşılayacak bir kadın olsun (Raik'in Annesi 1982: 139).”

Dönemin panoramasını vermesi yönünden önemli olan bu cümlelerde, okurun karşısına iki tip kadın çıkar: Modanın rüzgarına kapılmış dejenere Türk kadını (Necibe) ile eğitimli, inançlı Müslüman Türk kadını (Refika). Yazar, bu iki kadın tipinden birincisini eleştirip reddederken, ikinci tip kadını savunur. Bu ikinci tip kadın eğitimli, camiye giden, gönlü imanla dolu bir annedir. Bu bakımdan, savunulan ve özlenen bu kadın tipinin en önemli özelliği "din" duygusuna sahip olmasıdır. Böylece Halide Edib, bir taraftan yanlış batılılaşmayla kendi değerlerinden uzaklaşan toplumda, tekrardan millî kimliği bulup korumada "din"in ve dindar kadının önemini vurgulamaktadır.

\section{Seviye Talip (1910): Geleneğin Direnç Çizgisi "Din"}

Yazarın "Raik'in Annesi" romanından sonra kaleme aldığ yeniliğe karşı direnen geleneğin önemli bir unsuru olmakla birlikte, manevî havasıyla ruhları 1sıtan bir değer olarak okuyucunun karşısına çıkar. Bu romanda din, günlük hayatın bir öğesi olarak âdeta bir dekor hâlinde yer almaktadır.

İngiltere'de felsefe öğrenimi gördükten sonra II. Meşrutiyet'in ilanıyla birlikte (1908) yurda dönen Fahir, eşi Macide'nin değişen şartlara uyum sağlamasını ve yeni tip" hürriyet kadını" olmasını ister. Oysa Macide, yazarın diğer romanlarında sağlam Türk kadınının ilk örneği olan annesinin evinde, geleneğe bağlı olarak yetiştirilmiş bir Müslüman Türk kadınıdır (Enginün, 2007: 99). Bu sebeple, Fahir'in gelmesinden iki ay sonra Numan'ın karşısına çıkmayı Türk ve Müslüman âdet ve inanışlarına aykırı bulur:

“- Bak sana söyleyeyim, Fahir! Ben Türk kızıyım. Senin gibi Ingiltere'de bulunmadım. Frenk karıları gibi öyle açık saçık yabancı erkeklerin yanına çıkamam (Adivar, 1973/a: 21)."

“- ... Ben Türk kızıyım, Müslüman kızıyım (Adivar, 1973/a: 21).”

$\mathrm{Bu}$ sözler, geleneğin içinde "din"in ehemmiyetini gösterir. Zira, Macide'nin yeniliğe karşı direnç göstererek Numan'ın karşısına çıkmayı istememesi, geleneğin halktan gelen ataerkil bir din anlayışının kadını kapatmasıyla ilgilidir. Ancak, Halide Edib'in bu durumu savunduğuna dair bir iz yoktur.

Eserde "din"in toplumdaki yerini gösteren diğer bölüm, eserin "sonuç" bölümüdür. Bu bölümde şehitler adına mevlit düzenlenmektedir ve Halide Edib burada mevlidin düzenlendiği camiye, camiyi dolduran cemaate son derece saygıll ve hürmetkâr bir üslup kullanır:

"Camiin kurşunî kubbelerinden altın ışılklar kayıp ibadetçilerin huşûla eğilen başlarını yakıyor. Ulu, ahenkli bir ses, camiin sade duvarlarında akisler yaparak, derin bir ibadet hissi ile mahzun ve başı eğik bir kendinden geçişle dinleyenlerin ruhlarını ıslatıyor. Hıçkıran çocuklar, mendilleri ağızlarında, inleyen kadinlar var. 
Hürriyet şehitlerinin ruhuna mevlût okunuyor. Köşeleri boş kalmış evler, eşyaların kaybetmiş kadınlar, orada, dinin ululuğundan, esirliğinden birer damla teselli ve sabır dileniyorlar... (Adivar 1973/a: 128)."

Macide'nin de katıldığ 1 bu mevlit ayininde cami - cemaat bütünleşmesi vardır ve din, herkes için bir sığınak ve teselli kaynağıdır. Bu mevlit sahnesi Halide Edib'in Vurun Kahpeye ve Sinekli Bakkal romanlarında görülen mevlit ayinine duyduğu hayranlığın ilk örneğidir.

\section{Handan (1912): Müsamahalı Din Anlayışının İlk Örneği}

Halide Edib'in mektup tekniğiyle yazdığı bu roman, Handan adlı kadının bahtsız evliliği ve Refik Cemal'le yaşadığı buhranlı yasak aşkı konu edinir. Romanda, "Doğu-Batı çatışması" etrafında din önemli bir yer tutar. Hatta, yazarın önceki romanlarına kıyasla ilk defa bu romanında dinin, din eğitiminin sorgulandığını söyleyebiliriz. Zira önceki romanlarında sadece millî bir değer olarak görülen din, yaşanılan hayatın bir cephesi olarak görülürken, ilk defa Handan'da, toplumda öğretilen bir değer olarak arzu edilen ve reddedilen yönleriyle ele alınır.

Başta, roman kahramanlarının mektuplaşmalarından tanıdığımız Handan, çocuk yaşta "sakallı, sakalsız, sarıklı Kuran ve Arabî hocalarından (Adıvar 2017/a: 47)" dersler almıştır. Bu derslerin yanı sıra, çevrenin tesiriyle de Handan'da bir din algısı oluşmaya başlar. Handan'ın çocukken tanıdığı Allah, insanoğlunu daima cezalandıran, ona işkenceler eden, merhametsiz bir yaratıcıdır. Allah'ın böylesine acımasız olması, Cehennem'de yanacak olan milyonlarca insanı düşünen Handan'ın gecelerini kâbusa çevirir ve Handan, onlar için durmadan dua edip ağlar. Daha sonra Selim Bey'in temsil ettiği din algisıyla huzura kavuşan Handan, çocukluğunda korkulan nesne olarak tanıdığı bu din ve Allah algısına rağmen içinde, Allah'ın her şeye gücü yeten bir kudrete sahip olduğuna dair inancını korumaktadır. $\mathrm{Bu}$ inançla erken kaybettiği annesini bu kudretli yaratıcının dirilteceğine inanır:

"Onun dinden bahsedişini pek severim. Onun inandiğ Allah hiç de benim çocukluğumda söyledikleri gibi bu kadar çok ceza eden mabuda benzemez. Çocukluğumda tasavvur ettiğim Allah, kadir-i mutlak surette günahlart, sevapları tartardl, müthiş olan adaletine hiç de merhamet karıştırmazdl. En küçük yaramazlıkları bile görünmez bir gözün gözetlediğini ve bellediğini hissederdim. Çocukluğumun bütün neşesini kaçıran bu kudrette korkunç ezeli bir güzellik vardı. Bununla beraber yine içimde bir şey, bu insanlarl ve dünyalarl yaratan kudrette bütün kendi tabî kanunlarını ve hatta bizim fani dualarımızla değişstirecek bir şey olduğuna kani idim. İşte bu küçük kanaatle senelerce annemin dirileceğini bekledim, pek çok bekledim. (Adıvar 2017/a: 51)."

Handan'daki bu korku ve dine karşı olumsuz algı, ilerleyen zamanlarda Nazım'ın amcası olan Selim Bey'in temsil ettiği arzu edilen din algısıyla yıkılır. Nitekim Handan, Selim Bey'in daveti üzerine onun evine misafir olur ve ondan görüp öğrendikleriyle yazarın arzu ettiği "din”le tanışır. Handan'ın Selim Bey'de gördüğü arzu edilen din algısı ve eğitiminde Allah'ın umacı gibi duran bir tarafi yoktur. Onun, Selim Bey'de tanıdığı Allah, kudrete sahip olmakla birlikte daima 
ruha yakın duran, onu aydınlatan halaskâr bir yaratıcıdır. Bu durum, Handan'da çocukluğundan gelen ve korkulan bir yüce varlık olan Allah algısını değiştirir.

"Fakat Selim Bey'in tasavvur ettiği Allah, hiç böyle müthiş değilmiş. Benim eski hayalimdeki kadar kudret sahibi fakat namütenahi surette ruha yakın; insanların, eşyanın ensacında mevcut; ruhun karanlık ve çirkin boşluklarına kadar her şeyi dolduran halaskâr ve lütufkâr bir muhabbet ruhu (Adıvar 2017/a: 52)."

Handan, Selim Bey'in evinde misafir olduğu zamanlar, ondan duyup öğrendiği ve "vahdet-i vücut" felsefesini hatırlatan bu din ve Allah anlayışı ile herkesi kucaklayan bir insan hâline dönüşür. Artık Handan'daki din algısında öncesi ve sonrası vardır. $\mathrm{O}$, artık İslam'ın gerçek yönüyle karşılaştığına inanmaktadır:

"Isste Islamiyet, Selim Bey'in Islamiyet'i. Kimseyi cennetten kovmuyor. Kimseye, ama kimseye işkence etmiyor. Onlarca gecelerim cehenneme gidecek milyonca insanların işkencesi ve hayaliyle nasıl karanlık bir sira azap kâbusu olmuştu. Ne kadar yanmış, ağlamıştım. Hatta çok zaman namaz kılarken Allah'a beni başkaları yerine ebediyen yaksın da onları kurtarsın diye yalvarmıştım. Şimdi Selim Bey'i dinlerken bütün insaniyete kapısın a açan bir dine mensubiyet hissi geliyor. Hepsi günahkârlar ve sefiller, hepsi, hepsi yanmaktan kurtulacak ne güzel, ne samedanî bir şükranla doluyum (Adıvar, 2017/a: 52)."

Handan'ın şükran duyduğu bu din anlayışı, son derece müsamahalı, tüm insanlığı kucaklayan evrensel bir din anlayışıdır. Bu bakımdan Selim Bey ve onun temsil ettiği din anlayışı Vurun Kahpeye'deki Mevlevî dedesi ile Sinekli Bakkal romanındaki Vehbi Dede'nin ilk örneğidir (Enginün, 2007/: 231). Diğer taraftan Handan'daki kötü din algısının temsilcileri, bu romanlardaki Hacı Fettah Efendi ile Hacı İlhami Efendi'dir. Birbirine böylesine zıt iki farklı din alg1sı Halide Edib'in çocukluğundan kaynaklanmaktadır:

"Çocukluğunda, dinin korkutucu taraflarından bahseden bir kitap okuduğunu, konuşmalar dinlediğini, ancak Eyüp Sultan'a anneannesi ile gittiği zaman, cami ziyaretlerinde, mevlidlerde içini sonsuz bir iyilik ve sükûnetin kapladığını ve ancak bu şekilde dinin korkutucu cephesini unuttuğunu hatıralarında sik sik tekrarlayan Halide Edib, burada şahsi tecrübesini Handan'a yüklemektedir (Enginün, 2007/a: 113)."

\section{Yeni Turan (1912): Hoşgörülü Bir Din Arzusu}

Yazarın, Handan romanıyla aynı yıl (1912) tefrika edilen Yeni Turan roman1, dönemin iki önemli partisi olan Yeni Osmanlılar ile Yeni Turan arasındaki çatışmayı anlatır. "1932 Türkiye'sinin politik ve sosyal gelişmesini tasavvur eden (Enginün, 2007: 123)" bu romanda din, iki partinin halka karş1 söylemi olarak önemli bir yer tutar. Hamdi Paşa'nın liderlik ettiği Yeni Osmanlılar ile gerek memlekete hizmetleriyle gerekse de maddî, manevî millî değerlere önem vermesiyle hızla sevilip tutulan Yeni Turan arasında iktidar mücadelesi vardır. Bir nevi eski-yeni mücadelesi olan bu partiler arası çekişmede kurumları, kulüpleri ve salonları ile halk arasında sevilen ve oyları hızla artan Yeni Turan, yeniyi temsil etmektedir. Kendilerince bir çeşit Türk-İslam sentezi yaratan Yeni Turan, bu senteze uygun şekilde kadın, din ve eğitim meselelerinde ülke yararına fikirler 
üretmektedir. Bu bakımdan, hem kadının eğitimine önem veren hem de kadın erkek eşitliğini savunan Yeni Turan, din eğitiminde de son derece hassas davranarak resmî kurumların aksine dindar bir nesil yetiştirmektedir. Oysa Yeni Osmanlılar, Yeni Turan'ın bu üretken politikalarına karşı bir şey üretemez ve halk arasında kaybettiği yerini iftiraya dayanan yollarla tekrar kazanmak ister. Türlü iftira ve karalamalarla Yeni Turan'a saldıran Yeni Osmanlılar, dini kullanarak hedeflerine ulaşmaya başlar. Zira, Yeni Osmanlılara göre kadının ilerlemesi, iş hayatına karışıp söz sahibi olması dine aykırıdır:

"İşte hep, halkın maddî, manevî ruhuna girmeye başlayan Yeni Turan'ı gözden düşürmek için yaptığımız propaganda bundan ötürü etkisiz kaldı. Sonra başka ve fena bir yol tutturduk: Zaten bizim politikamızda bu değişmez bir vasita değil mi? Kadınların ilerlemesini, kadınların işe girmesini ve buna benzer birtakım davranışların İslamlığa dokunduğunu dilimize doladık. Zannedersem bunda daha çok başarılı olmaya başladık (Adıvar, 1973/b: 19)."

Yeni Osmanlılar'ın bu gayriahlâkî politikalarında başarılı olmalarının sebebi, halktır. Çünkü dönemin Osmanlı toplumunda sadece görünene önem veren, yeniliklere karşı dinî taassuba sığınan bir cahil güruhu vardır: "Fakat halk görünüşe aldanıyordu. Dini, komşusunun her hareketine karışma ve sirf her uygarca şeye karşı bir duvar bilen cahil takıma, bu yeni yetişen gençleri dinsiz göstermek kabildi (Adivar, 1973/b: 19)."

Yeni Osmanlılar'ın bu tavrı, İslam birliği politikasını benimsemeye kadar varır. Böylece Yeni Osmanlılar, Yeni Turan'ın yaydığı Türkçülüğe karşlık, Müslümanlar dağılıyor kampanyası başlatır. Bu kampanyayı bilhassa Araplar ve Kürtler arasında yayan Yeni Osmanlılar'a göre Yeni Turan, Hristiyanlığa yakın durmaktadır. Mutaassıp ve cahil halk, buna da inanmaktadır. Öyle ki, bu kör inanç ve mutaassıp zihniyet Oğuz'un, kadınların öğrenimi üzerine hazırladığı kanun taslağını dine aykırı bularak reddederken, romanın sonunda Oğuz'u da öldürür:

"Ve değil Kürt, Arap hatta Türkler bile bu gerçekten hayalî tehlikeyi doğru sanacak kadar henüz uykuda idiler. İște bunun için bu defa, bir kere daha, İslâmlı̆̆ öne sürerek taassup silahıyle, İslâmiyet'e hatta uygarlığa bir engel çıarmaktan bile çekinmeden, propagandaya başladık (Adıvar, 1973/b: 87)."

Yazar, Yeni Osmanlılara karşı almış olduğu bu eleştirel tavırla, toplumdaki iki tip insana karşı çıkmaktadır: Dini kullanıp yarar sağlamaya çalışanlar ve dini yeniliklere engel görenler.

Millî değerlere önem veren Yeni Turan, dini bu değerler içinde görüp, ona gereken ehemmiyeti verir. Yeni Turan'ın savunucuları bu yönüyle dindar görünen Yeni Osmanlılar'dan daha dindardır. Resmî okullarda dinsiz gençler yetiştirilirken onlar, açtığı kurumlarda din eğitimine önem verip dindar bir nesil yetiştirirler ve dini uygarlığa engel olarak görmezler:

"Fakat işin tuhafi biz güya dinin savunucusu olduğumuz halde onlar bizden çok dine bağllydılar. Yeni Turan okulları ilk güçlü ve tutucu şeklin almış olmakla beraber, resmî okulların yetiştirdiği dinsiz gençlere karşı tamamen uygar olmayı İslâmlığa aykirl görmeyen, bütün hayat görevleri ve uygarca eğlenceleri arasında 
bile ibadete yer veren gerçek dindar, bir alay Yeni Turan genci vardl. Halbuki okullar resmî okullar kadar da din bilgisi vermediği halde, oralarda yetişen ve bütün dinle ilgisiz gençleri Yeni Turan okulu yetiştirmiyordu (Adıvar, 1973/b: 19)."

İslam'ın uygarlığa engel olmadığını Yeni Turan'ın programını anlatan Oğuz da ifade eder. Ona göre bu asılsız iddianın asıl kaynağı Avrupa'dır:

"Yeni Turan, bütün komşularına mutlak bir mezhep hürriyeti vermekle kendisi ilk defa olarak dünyaya İslâmiyetin uygarlı̆̆a engel olmadı̆ğnı ispat edecek. Bugün, bizim yüzümüze uygar Avrupa'nın firlattı̆̆ en büyük "manevî darbe" nedir? "İslâmiyet uygarlıkla bağdaşmaz" iddiası değil mi? Ve bunu bize birer birer çöküp giden öbür Müslüman ülkelerini ve bizim Avrupa'daki başarısızlı̆̆ımızı göstererek, ispata çalışıyorlar (Adıvar, 1973/b: 39).”

Gerek Yeni Turan'ın faaliyetleri ile onun sözcüsü olan Oğuz'un bu sözleri, gerekse de Yeni Osmanlılar'ın faaliyetleri yazarın nasıl bir din anlayışına sahip olduğunu göstermektedir. Buna göre, romanda yer alan din hakkındaki görüşleri şu maddelerle özetleyebiliriz:

a) Din, siyasete karıştırılmamalıdır. Bu bakımdan Halide Edib, laik bir anlayışa sahiptir.

b) İslam, uygarlığa engel bir din değildir, ancak İslamı yanlış yorumlayıp buna engeldir.

c) İslam, kadının toplumsallığını sınırlandırmaz.

d) Okullarda din eğitimine gereken önem verilmelidir.

\section{Son Eseri (1913): Yabancı Okullarda Misyonerlik Faaliyeti}

Vakası itibariyle evli ve iki çocuk babası olan Feridun Hikmet'in Kâmuran'la yaşadığ1 aşkı anlatan bu romanda din, yabanc1 okullarda eğitim gören Türk çocuklarının Hristiyanlaştırılmasını anlatması bakımından önemlidir. Yazar, Kâmuran'ın Feridun Hikmet'e yazığı mektupta bu tehlikeye dikkat çekmektedir. Buna göre Kâmuran, abisi Asım'ın Paris'e üçüncü kâtip olduğu sırada Dame de Sion mektebine verilir. Burada hocası olan Hemşire Terese ile Kâmuran, aralarındaki yaş farkına rağmen dost olurlar. Ancak Hemşire Terese kuvvetli bir katoliktir ve yakın arkadaşl1k kurduğu Kâmuran'ı da Hristiyan yapmaya çalışır: "Tabii olarak kuvvetli bir Katolikti. Beni de Hristiyan yapmaya içten içe uğraştı (Adıvar, 2016/a: 93)." Hemşire Terese'nin bu misyoner tutumu, Kâmuran'da bir ters tepkiye neden olur ve kuvvetli bir Müslüman olarak okuldan çıkar:

"Belki bir aksülamel, belki mizacımın tesiri, herhalde Dame de Sion'dan kuvvetli bir Müslüman olarak çıtım. Neyse bu yeni yetişen bir klz için iyi bir şey çünkü insana deruni bir ahlâk inzibatı aşıllyyor. Azıcık da vaktinden evvel koca düşünmek, önüne gelen gence âş̧ı olmak gibi o yaşta çocukları haylaz yapan şeylerden kurtarlyor.

Hemşire Terese'nin tesiriyle benim kadın kahramanlarım Allah'a âşı olanlar, insaniyete ömrünü vakfedenlerdi. Ders, musiki, resim. Hemşire Terese ve o zamanlarda beş vakit kıldığım namaz kalbimi, kafamı doldurdu (Adıvar, 2016/a: 93)." 
Kâmuran'ın bu tavrı, yazarın biyografisiyle yakından alakalıdır. Çünkü Kâmuran gibi Halide Edib de yetişme çağında yoğun bir şekilde Hristiyan tesiri altında kalmıştır. Ancak o, bu tesire karşı çocuk yaşta, özellikle anneannesinin evinde aldığı İslamî terbiye ile karşı koymuştur (Enginün, 2007: 36). Bu yönüyle yazarın, çocuğun erken yaşta din eğitimini aileden alması gerektiğini de vurguladığını söyleyebiliriz.

\section{Vurun Kahpeye (1923): Dinî Taassubun İhanetle Birleşimi}

Vurun Kahpe'ye romanında "din", Handan romanından daha derinlemesine, arzulanan ve karşı çıkılıp eleştirilen yönleriyle okuyucuya sunulmuştur. Yazar, roman kişileri üzerinden iki farklı din anlayışını ele almıştır. İlk olarak din eğitimini ve ataerkil düzeni koruyan din anlayışıyla kadın yaşantısını değerlendirmiştir. Böylece toplumda söz sahibi olan din adamları meselesini sorgulamıştır. İkinci olarak da cami ve mevlit gibi dinî merasimlere bakış açısını Aliye üzerinden anlatmıştır.

Halide Edib, Handan ve Yeni Turan romanlarında eleştirel bir üslupla değindiği dinî eğitimin kim tarafından, nasıl verileceği meselesine bu romanında da yer vermiş̧ir. Yazar, dinî terbiyenin bireye çocuk yaşta verilmesi taraftarıdır. Ancak, çocuğun ulusal kimliğini inşa etmesinde önemli olan bu dinî terbiye, uygun kişiler tarafından verilmelidir. Yanlış kişiler tarafından verilen dinî terbiye, ilerleyen zamanda bireyin dini yanlış tanımasına; hatta genel olarak toplumda ileri derecede mutaassıp bir zümrenin oluşmasına sebep olabilir. Bu istenmeyen durum, toplumsal ilerlemeye engel olduğu gibi, çeşitli facialara da sebep olabilir. $\mathrm{Bu}$ romanda, “..." kasabasında Aliye ile birlikte ikinci muallime olan Hatice Hanım ve onun verdiği dinî terbiye eleştirel bir üslupla anlatılır.

Maarif Müdürü'nün kirli işlerine ortak olan, elinden düşürmediği sigarasıyla öğrenciler arasında adaleti gözetmeyen ikinci muallime Hatice Hanım, kişiliği ve çocuklara verdiği eğitimle öğretmenlik vasfını hak etmeyen bir kadındır. Ailelerine göre öğrencilere muamele eden Hatice Hanım, girdiği sınıflarda düşünceye yer vermeyen ve sadece bazı sure ve duaların ezberine dayanan bir dinî eğitim verir: "Efendim, benim sinıfimda her çocuk namaz surelerini bilir. Hiç olmazsa amme cüzünün sonuna kadar ezberlerler (Adıvar, 2017/b: 53).” Ayrıca o, kişinin dindar olup olmadığına kılık kıyafetine göre karar veren olumsuz bir tiptir:

"Yeni hanımlar hep dinsizlik, milliyetsizlik ögretiyor. Ben dokuz yaşında kızların bile yüzlerini siyah peçelerle kapadım. Halbuki İstanbul'dan yeni gelenler kendi yüzleri açık geziyorlar. Şimdi on üç yaşında bâligalar saçlarını açıyorlar. Artık bunların terbiyesi sayenizde inşallah verilir de... (Adıvar, 2017/b: 53-54)."

$\mathrm{Bu}$ düşünceleriyle Aliye'ye karşı Tosun Paşa'yı kışkırtmayı hedefleyen Hatice Hanım, yazarın olumsuzladığı bir eğitimcidir. Yazar, onu sözünü emanet ettiği Tosun Paşa aracılı̆̆ıyla eleştirir: "Muallime Hanım, namus kadının yüzünü açıp açmamasında değildir. Din de peçe demek değildir. Öyle kapalı kadınlar vardır ki kapı arasindan her türlü rezaleti yaparlar (Adıvar, 2017/b: 54)."

Kadını taktığı peçeye göre dindar veya dinsiz gören bu anlayış, Hacı Fettah Efendi'de daha ileri boyuta varır. Dinin taassup yönünü temsil eden Hacı Fettah 
Efendi, bir cuma günü, cuma namazı vaktinde öğrencilerini marşlar eşliğinde gezmeye çıkaran Aliye'yi başı açık erkekler arasında görünce halkı galeyana getirmeye çalışır. "Nitekim, dinsel bağnazlığın bedenselleşmesi olarak kurgulanan Hacı Fettah, Aliye'nin yüzü açık varlı̆̆ını, halka, Allah'ın iradesine karşı bir "meydan okuma" olarak sunar ve onun kapatılmast ya da yok edilmesi için halkı harekete geçirmeye çallşır (Aytemiz, 2015: 178)."

"-Görüyor musunuz? Erkeklerin içinde yüzü gözü açık namahremler Müslümanların kalbini fesada vermek için şark söyleyerek dolaşlyorlar. Bunlar, bunlar mel'undur, bunların eline çocuklarınızı teslim etmeyiniz, eğer bir gün yalnız içimize Yunan girdiğini değil, başımıza taş yağdı̆̆ını görmek istemiyorsanız, bu karlların üstleri başlarlyla beraber kendilerini de parçalayınız, yoksa Cenabı Hakk'ın gazâpları üzerimizden eksik olmayacaktır (Adıvar, 2017/b: 45).”

Hacı Fettah'a göre Aliye, dinsiz olduğu kadar namussuzdur. Namuslu olsaydı yüzü gözü açık gezmezdi (Adıvar, 2017/b: 47). Onun kin ve öfkeyle dolu olan bu yaklaşımı, Aliye'nin Tosun Paşa'yla nişanlanması üzerine daha da artar. Aslında Hacı Fettah Efendi'nin bu tavrı, dinden öte ataerkil bir söylemden gelmektedir. Bu bakımdan Halide Edib, ataerkil bir anlayışa göre yorumlanan dine karşıdır. Zira, böyle anlayışta kadının toplumdaki yeri, cinsel obje olmaktan öteye gidemez.

Romanda sorgulanan diğer mesele, dinin uygulayıcısı ve toplumda söz sahibi olması bakımından din adamlığı meselesidir. Yazar, bu mesele üzerine romanında iki farklı din adamı tipi kurgulamıştır. Böylece reddedilen ve arzu edilen iki farklı din anlayışını ortaya koymuştur: Hacı Fettah Efendi ve İstanbullu isimsiz Mevlevî dedesi. Bu iki tipin Sinekli Bakkal'daki devamı Hacı İlhami Efendi ile Vehbi Dede'dir (Enginün, 2007: 192).

$\mathrm{Bu}$ tiplerden birincisi çıkarcı, paraya düşkün ve yobaz Hacı Fettah Efendi'dir. Kasaba halkı tarafından sözüne kulak verilen bu din adamı, tarlasına el koymak için Ömer Efendi'yi kurban etmekten çekinmeyen, her bakımdan kötü, merhametsiz ve riyakâr biridir. Halide Edib, bu olumsuz özellikleri en baştan okuyucuya hissetirmek için, onu sembolik bir şekilde, beyaz minareli eski ve güzel olan meydan camiinin önünde koyu bir kütle (Adıvar, 2017/b: 43) olarak tanitır. Daima kendi çıkarlarına göre hareket eden bu adam, memleketi Yunanlılara karşı savunan Kuva-yı Milliye aleyhtarıdır. Çünkü, onlar din düşmanıdırlar ve onların kanını dökmek helâldir düşüncesini savunmaktadır:

"Bıyıksızları, gâvurlar gibi yakalık takanları, din düşmanı olanları istemeyiniz! Onlar ki ellerine kudret geçer geçmez mukaddesatı çiğner, kadınlarımızın örtülerini kaldırır, sünnet ve farzı inkâr ederler. Onları istemeyiniz! Ey ahali, onların kanı kâfirlerin kanı gibi helaldir.

Hatta derim ki, herhangi bir kuvvet ve hükûmet nereden gelir ve kim olursa olsun, camilerimiz, dinimizi siyanet ederse ona biat ediniz (Adıvar, 2017/b: 4243).”

Hacı Fettah Efendi'nin, yeni düzenin habercisi olan Kuva-yı Milliye'ye karşı çıkarken sergilediği bu düşmanca tutum, Yunan ordusu kumandanı Damyonas'la ortak hareket etmeye kadar varır. Zira, kasaba Yunanlılar tarafindan işgal 
edildiğinde halk, bir din adamı olan Hacı Fettah Efendi'nin ferasetinden ve kutsiyetinden medet umarken, $\mathrm{o}$, bu vesileyle düşmanlarını kahredeceği için mutludur. Bu bakımdan onun temsil ettiği din, kendi çıkarları için faydalandığı bir kurumdur:

"Bu zampara herifleri de, kahpeleri de gebertecekti, fakat evvela bu günahkâr kadınların güzellerini Yunanlılara teslim ederek Yunanlıların kendi itibarını arttıracak, sonra bu karıları şeriatın emrettiği cezayı millete taşlattırarak yaptıracak ve bu suretle Allah'ın rizasını kendi üzerine celbedecekti. Kim bilir, Yunanlılar yerleștikten sonra bir daha hacca gidecekti (Adivar, 2017/b: 93).'

Hac1 Fettah Efendi'nin kadınları Yunanlılara verip sonra, onları taşlattırması ironik olmakla birlikte onun dinî cephesindeki çelişkiyi de gösterir. Zaten, onun en önemli özelliği içinde bulunduğu şartlara ve çıkarlarına göre davranmasıdır. Güç karşısında daima korkan Hacı Fettah Efendi, kanlarını helâl gördüğü Kuva-yı Milliye'nin kasabaya girmesiyle taraf değiştirerek, bir vatanperver gibi "Biz, kendi ordumuz girmeden, burada şeriatın namusunu temizleyeceğiz, izzet ve şerefini yükselteceğiz (Adıvar, 2017/b: 194)" diyerek İslam'a ihanet edenleri cezalandırmak için harekete geçer.

Din adamını temsil eden ikinci tip, İstanbul'lu Mevlevî dededir ve yazarın arzu ettiği din adamını temsil eder. Bu bakımdan İstanbullu Dede, etrafına Hacı Fettah Efendi'nin aksine huzur ve ferahlık verir:

"Dede, ışı̆̆ın tesiriyle kafeslerin arkasında uzak ve rüyaya benzeyen bir ziya içinde oturuyordu. Sarl yüzlü çenesine doğru incelen, seyrek ve beyaz sakallı bir ihtiyardl. Sikkesinin tevazu ile eğilen başl, bol harmanisinin kıvrımları altında dindar ve zarif bir huşu ile düşen zaylf ve ihtiyar omuzlar mevlidin ahengiyle yavaş yavaş sallaniyordu. Bütün bu dalgalanma ile kandiller, ibadet edenler, havanin ışıları ve buhur dumanları, hatta cami, tutulamayan ilahî bir vecd içinde hemahenk dalgalaniyordu (Adivar, 2017/b: 85)."

Okuyucu bu satırlarla dedenin vaaz verdiği halka, durmadan galiz sesiyle vecd ve huşû yerine korku ve öfke veren Hac1 Fettah Efendi'den farklı olduğunu hisseder. Aliye, mevlit gecesinde İstanbullu Dede'nin gönüllere sükûn veren tavrı ve Mevlevîliğin asırlardan bu yana gelen ince ve heyecan verici sesiyle çocukluğuna geri döner. Çünkü, bu "Dede'nin derin yüzü, güzel sesi onu Allah'a temas eden bir vecdiyle sarsmıştı (Adıvar, 2017/b: 86)." Bu dakikalarda Aliye, Hacı Fettah Efendi ile İstanbullu Dede arasındaki farkı düşünür. Biri kendisine cehennem ve azap dolu dakikalar yaratırken; diğeri gönlünü huzur ve merhametle doldurur. $\mathrm{Bu}$ tezat, rahmet ve huzur dini olan İslamiyet'te Hacı Fettah Efendi gibi tiplerin nasıl ortaya çıktığını düşündürür: "Nasıl olur da bu kadar beşerî, bu kadar merhamet ve iyilik dolu bir dinden Hacı Fettah Efendi o kadar kâbusa benzeyen bir azâb ve işkence çıkarıyordu (Adivar, 2017/b: 86)."

İstanbullu Dede'nin temsil ettiği din adamlığı ve din anlayışı Selim Bey'le başlayan ve Vehbi Dede'yle devam edecek olan evrensel, müsamahalı ve beşerî bir din anlayışıdır. Yazıldığı dönemde, din aleyhtarı bir roman olarak yanlış anlaşılan bu roman, İstanbullu Dede'nin temsil ettiği değerler noktasından okunursa, yazarın 
niyetinin hiç de kötü olmadığı anlaşılır. Zira yazarın, bu romanında dine karşı menfi bir tavrı yoktur. Sinekli Bakkal'da da görüleceği gibi, dini yanlış anlatan ve tanıtan din adamı tipi eleştirilmiştir. Çünkü bu tipler, bir taraftan dini çıkarları doğrultusunda kullanırken, diğer taraftan dini eli sopalı bir umacı gibi göstermektedirler. Neticede, İstanbullu Dede'nin yazar tarafindan romana sokulması anlamlıdır. "Bu bağlamda Dede'nin Hacı Fettah Efendi gibi caminin dışına değil de içine konumlandırlması dikkat çekicidir. Yazar, temsil ettiği değerlerle olumsuzlanan Hacı Fettah'ı kutsal mekânın dışında tutmak için âdeta özen göstermiştir (Aytemiz, 2015: 182)."

Vurun Kahpe'ye romanında dinî tavır açısından önemli olan diğer nokta ise, yazarın İslam'ın ibadet merkezi olan camiye ve bu camide şehitler adına okunan mevlide yaklaşımıdır. Zira Halide Edib, Seviye Talip romanında olduğu gibi cami ve mevlit törenini saygılı ve hayranlık belirten bir üslupla anlatır. "Beyaz minareli eski ve güzel camii, göz kamaştırıcı, göğe dayanmış, eski bir kabartma gibi (Adıvar, 2017/b: 43)" duran kasaba camii, Yunanlıların şehri işgal ettiği gün, sembolik şekilde siyahlar ortasinda, beyaz minaresiyle belirir:

"Siyah meydanda beyaz cami, narin minaresiyle, güzel ve ezeli gök altında hülyalı ve yumuşak hatlarla beliriyor, her taraftan ellerinde fener, camiye giden ahali, nur taşıyan birer karanlık hayalet gibi kımıldanıyordu (Adıvar, 2017/b: 83)."

Aliye, bu camiye girdiği ilk andan itibaren manevî bir büyülenme hissî yaşar ve ruhu, o ana kadar duymadığ bir vecdle dolar:

"Minarenin ezelî teranesi, camiin hülyalı ve hafif nurlarl, buhurdanlardan çıkan mukaddes ve bayıltıcı kokular, bütün bu güzel ibadet dünyası, Aliye'nin bakir ruhunun heyecanında ölüme götüren istigrak lerzesi yapmışt. Benliği tamamıyla ilk güneş gören bir gonca, mucize ile gözleri açılan bir kör gibi dünyayı ilk defa şimdiye kadar sezemediği yeni heyecanları, meçhul lezzetler ve aziz işkencelerle hissediyordu (Adivar, 2017/b: 84).

Bu ruhanî ortamda Aliye'yi en çok mevlidin velâdet kısmı sarsar. Dede'nin şarkın hüzün ve esrarıyla okuduğu bu kısımda Aliye, Hazret-i Âmine'nin doğum anını hayal eder. Bu esnada, diğer kadınların Bakkal Salim'in dul karısına dışlayan gözlerle bakması, Aliye'ye İslam'ın esaslarıyla uyuşmayan bu tutumun izah edilemez olduğunu gösterir:

"Hele her satırının ve kelimesinin ilahi güzelliğini içer gibi dinlediği bu büyük menkıbenin ruhuyla kadınların hareketini zıt buluyordu. Doğduğu an, günahkâr ümmeti için Cenab-ı Hakk'tan af dileyen ve "Şefiül-Müminin", "ve kamu düşmüşlere destgîr" diye selamlanan Peygamberimizin ümmeti, nasıl günahkârlara ve düşmüşlere hakaretle bakabilirlerdi? (Adıvar, 2017/b: 88)."

Aliye, bu mevlit gecesinde yaşadığ 1 cezbeyi, kasaba halkı tarafından taassuba kurban edildiği anlarda da hatırlar.

Sonuç olarak Halide Edib, Vurun Kahpeye romanında "Müslüman bir ülkede kadın sorununun dinsel söylemden bă̆ımsız gündeme alınamayacă̆ının ayırdındaki yazar, özellikle kişilerin şahsında temsil edilen dinsel bă̆nazlıkla hesaplaşmaya girişir (Aytemiz, 2015: 171)" ve bu hesaplaşmada reddedilen ve arzu 
edilen din algısına uygun birbirine zıt tipler yaratarak düşüncelerini söyleme firsatı bulmuştur.

\section{Kalp Ăgrısı (1924): Sükûn Kaynağı Olarak Din}

Başta Zeyno olmak üzere Saffet, Hasan ve Azize'de aşkın sebep olduğu kalp ağrılarını anlatan bu romanda din, romanın başkişisi olan Zeyno'nun buhranlı zamanlarında insana huzur veren bir sığınak olarak karşımıza çıkar. Buna göre Zeyno, intihar eden Azize'nin sağlığı için Hasan Bey'le olan ilişkilerini gözden geçirerek bir fedakârlık yapmaya karar verir. Ancak bu fedakârlık için Zeyno, kendi benliğiyle bir mücadeleye girer ve zayıf düşer. Zeyno, bir "ruh idmanı" olarak gördüğü bu mücadelede kalbindeki zaafi yok etmesi için Allah'a yalvarmak ister: "Bazen sokaklardan geçerken herhangi bir mahalle camiinin yıpranmış çuha perdeli kapısindan dalmak, karanlık, rutubetli bir köşede kalbimdeki zaafi silmesi için Allah'a yalvarmak isterdim (Adıvar, 2016/b: 53)."

Zeyno, benliğiyle giriştiği bu mücadelede gittikçe zayıflar ve bir gün buhran geçirir. Bu buhranlı anda onu kendisine getiren şey, ezan sesidir:

"Bir gün sabaha kadar geçirdiğim kötü bir buhrandan sonra mahalleye yeni gelen bir müezzinin çok sıcak ve ilahî bir sesle okuduğu sabah ezanı gözlerimden yaşlar akıtarak içimdeki zehri eritti. Sira ile birkaç zaman sabah ezanıyla uyanıyor, müezzini dinliyordum; ve her defasında gözlerimden boşanan yaşlarla sükûn buluyorum (Adivar, 2016/b: 53)."

Romandaki bu dinî yönün Zeyno'nun şahsında verilmesi önemlidir. Çünkü Zeyno, "sıhhatli, tabî̂ yetişmiş, Batı kültürünü almış, fakat köklerine bağll, hattâ muhafazakâr bir genç kaz (Enginün, 2007: 205)" olarak ideal bir kadındır. Böyle bir kadının, zaafları için Allah'a sı̆̆ınıp ezanda teselliyi bulması, yazarın kişinin ruh dünyası açısından dinin önemli bir yeri olduğunu vurgulamayı amaçladığını gösterir

\section{Zeyno'nun Ŏglu (1927): Toplumsal Bir Silah Olark Kullanılan Din}

Hasan Bey'in oğlu Haso Çocuk'un zorlu macerasını anlatan ve Kalp A ̈rrısı romanının devamı olan bu eserde din meselesi, vaka içerisinde güçlü bir yere sahiptir. Yazar, bu din meselesine roman kişileri üzerinden yaklaşarak arzu edilen ve reddedilen din anlayışını bir kez daha dile getirmiştir.

Romanda reddedilen din anlayışı, bir Kürt isyancısı olan Şeyh M... tarafindan temsil edilir. Vurun Kahpeye romanının düssmanla birleşen din adamı Hacı Fettah Efendi'yi hatırlatan Şeyh M..., Diyarbakır eşrafından olup Kuva-yı Milliye aleyhtarlı̆̆ ile meşhurdur. Onun en önemli iki özelliğii, Diyarbakır'da çok sayıda müridi olan bir din adamı ve Kürt milliyetçisi olmasıdır. Bu yönleriyle o, Bitlis'te başlayıp Diyarbakır'a sıçrayan Kürt isyanına destek vermektedir. Nitekim, onun Haso Çocuk'u yanına aldırtıp yetiştirmesinin sebebi de budur. Zira, adını Sakarya Zaferi'nden alan, at yarışında birinci olan Haso Çocuk'u nüfuzunu kullanarak yanına alan Şeyh, onu dinî telkinleri ve milliyetçi görüşleriyle eğitmeye başlar. $\mathrm{Bu}$ bağlamda Şeyh M..., Haso Çocuk'a başta din ve Kürtçe dersi verir. Onun üzerindeki tesiri arttırmak için, bir Türk köylüsü olan Şaban Amca'dan uzaklaştırır ve çocuğun zabitlere olan öfkesini sezdikten sonra onların "dinsiz ve zalim (Adıvar, 2010/a: 134)" olduğunu firsat buldukça söyler." Gözlerinde emeline herkesi sürüklemek ve 
alet etmek için bir din meşalesi yakan bu garip insan (Adıvar, 2010/a: 281)"1n Haso Çocuk'a karşı dilinden düşürmediği tek şey kan, zulüm ve işkencedir:

"Şeyh bugünlerde ihtilâl ve imhanin bir peygamberi gibi hazırlamakta olduğu firtınanın hummasını Haso'nun damarlarına aşılamaya çalışıordu. Şeyh, karşısındakinin dokuz yaşında bir çocuk olduğunu unutuyor, ateş, kan ve heyecan dolu rüyalardan, çocuğun muhayyilesinde korkunç beşeri tayfunlar uyandırtyordu (Adivar, 2010/a: 281).'

Şeyh M..., Kürt milliyetçiliğiyle daha gaddar bir hâl alan dinî taassubuyla Türklerin, bilhassa İstanbulluların Allah tarafından cezalandırılacağına inanır. Buna göre Allah, onları yok etmek için Şeyh M...'yi görevlendirmiştir. Ancak onların yok edilmesi için önce Hasan Bey öldürülmelidir:

"Şeyh evvela İstanbulluların zalim, günahkâr ve fena insanlar olduklarını, bunları yeryüzünden kaldırmak için Cenab-ı Hakk'ın kendisini memur ettğini uzun uzadıya anlatmıştı. Bunu o kadar eski ve karışık hikâyelerle izah ediyordu ki, çocuk şeyhin anlattıklarını tabî̀ olarak masal diye dinliyordu. Bilhassa şeyh, Istanbulluları Kavm-i Lût'a teşbih ediyor, hayatlarından garip misaller alıyordu. Fakat, bütün bu Kavm-i Lût'u ortadan kaldırmak için Hücum Taburu Kumandanı Hasan Bey'i ödürmek lâzımdı (Adıvar, 2010/a: 282)."

Halide Edib, sadece din anlayışını sakat bulduğu Şeyh M...'yi eleştirmez. Aynı zamanda ona inanan ve bağlanan cemaati de inançları noktasında samimiyetsiz bularak eleştirir. Buna göre Şeyh'in muhitinde din, şeyhin varlığına göre kendisini gösterir. Rekabetin, ihtirasın eksik olmadığı, durmadan türlü hesaplaşmaların yaşandığı bu çevrede "akşam namazı biter bitmez Şeyh'in yanında daima düşünülen Allah, aralarından çekilip gidiyordu (Adıvar, 2010/a: 134)."

Romanda Şeyh M... ve ona inanan müritlerinin karşısında Şaban Amca ve Saffet bulunur. Bu iki şahıstan Şaban Amca, Haso Çocuk ve anası Kürt Zeyno'nun Ramazan'dan gördüğü işkenceleri düşünerek hiçbir Müslümanın, bir insanı geçmişinden ötürü cezalandıramayacağını söyler. Bu yönüyle o, çocuğun doğuştan masum olduğuna inanan ve daima insanlara merhametle yaklaşan bir din anlayışını temsil eder.

Saffet ise, din ve komünizm hakkındaki görüşleriyle Halide Edib'in sözcüsü gibidir. Buna göre Batı, maneviyatını kaybettiği için ruhsuz kalıp çökmeye başlamıştır. Komünizm gibi maddeci düşünceler, onları bu çöküşten kurtaramaz. Toplumda giderek artan dinsizliğin sebebi ise bâtıl fikirlere inanıp akıldan uzaklaşılmasıdır. Böylece Halide Edib, komünizmi reddedeken, ona karşı akla dayanan bir dini savunur:

"Eski dinlerin sukutunu da dünyanın muvazenesini bozan sebepler arasından görüyorum. Bu dinî sukut, tabî̀ olarak birtakım ahlâkî kıymetleri ortadan kaldırdl. Dinsizliğin birçok sebeplerinden biri de esasen fikirden ziyade hülya, ruhtan ziyade bâtıl fikirlerle dolan dinlerin artık insanları tatmin etmemesi olduğunu da ilave edeyim (Adıvar, 2010/a: 248).'

Burada vurgulanması gereken hususlardan biri de şudur, yazarın önceki bazı romanlarında (Vurun Kahpe'ye, Sinekli Bakkal gibi) olumlu tipler olarak 
anlattığı Mevlevî dedelerin zıttına bu romanda Tasavvufî İslamın diğer bir akımının (Nakşıbendilik) temsilcisi olan "şeyhlik" kurumunun olumsuzlandığı görülmektedir.

\section{Sinekli Bakkal (1936): Așk ve Din}

Sinekli Bakkal roman1, II.Abdülhamit Dönemi (1876-1908) bir mahalleye sıkıştırılmış panaromasını hikâye eder. Bu bağlamda yazar, romanında istibdâd, din, muzik, toplumsal hayatta kadının yeri, batılılaşma ile başlayan eski-yeni çatışması gibi pek çok konuyu ele almışır. Ancak, romanın geneline baktığımızda yazarın, "din" konusuna tıpkı Vurun Kahpeye romanında olduğu gibi diğer meselelerden daha geniş bir yer verdiği söylenebilir.

Romanın yazıldığı tarih göz önünde bulundurulduğunda yeni kurulan bir devlette din, laikliğin gereği gibi görülerek toplumsallı̆̆ını gittikçe yitirmekte ve bireyin iç dünyasına hapsolmaktadır. Eski-yeni mücadelesinin devam ettiği böyle bir ortamda din, kimi çevrelerce irtica faaliyeti olarak bir tehlike sayılırken, kimi çevrelerde de "Din elden gidiyor." endişesine yol açmıştır. Böyle bir ortamda Türkiye'nin problemleriyle daima ilgilenen Halide Edib, Vurun Kahpeye romanından sonra bu romanıyla da "din" problemine etraflıca el atmış ve laiklik konusundaki fikirlerini roman kahramanları üzerinden aktarmaya çalışmıştır. Dolayısıyla yazar, eser boyunca din ve din adamı, din anlayışının erkeğe göre yorumlandığı bir toplumda kadının toplumsal hayattaki dinî kimliği de sorgulanmaya çalışılmıştır. Buna göre çağdaşlaşma taraftarı olan yazar, dini, millî kültür ve fert için vazgeçilmez bir değer olarak çağdaşlaşmaya bir engel saymaz. Marksist, pozitivist ve ihtilâlci düşünceleri zararlı bulan Halide Edib, dini, bu fikirlere karşı set olarak görür. Yazarın bu özelliğini Yahya Kemal Beyatlı. "müthiş bir softa düşmanı şeklinde ifade etmektedir. Tıpk1 romanda (Beyatl1, 2006: 38)” Hacı İlhami Efendi ve daima müsamahal, merhamete dayanan bir din anlayışı olan Vehbi Efendi'yi savunan yazar, toplumda söz sahibi olan din adamı sorununa temkinli yaklaşır. Çünkü din, onların elinde bir silaha dönüşebilir veya bir nesle din yanlış tanıtılabilir. Ayrıca Vurun Kahpeye romanında olduğu gibi ataerkil bir düzene uydurulmuş bir din anlayışında kadının toplumsallığı da eserdeki ana problemlerden biridir. Roman kişilerini dine yaklaşımları açısından iki grupta toplamak mümkündür: İbadetini aksatan, ama iyi insan Tevfik ve Rakım ile; dini reddeden, fakat ondan yararlanmaktan da vaz geçmeyen İhtilâlciler, Hacı İlhami Efendi ve Peregrini gibi.

Buna göre Sinekli Bakkal romanında, yazarın eleştirip reddettiği din adamı Hacı İlhami Efendi'dir. Yazar, daha eserin başında tanıttığı Hacı İlhami Efendi'ye karşı mesafesini belirtmek için onu kötü tasvir eder:

"Kirpi kalları gibi ayakta duran iki kalın kaş, içeriye çökmüş, kömür gibi siyah, kar gibi yakıcl, burgu gibi keskin iki göz. Burun uzun ve tilkivâri. Kara sakal hayli kırlaşmış. Boyu kısa, vücudu cllızdır. Fakat beyaz sarı̆̆ın kallâviliği, geniş yenli lâtanın içinde ağır ağır sallana sallana yürüyüşü ona husûsi bir heybet verir.

Iri yarı erkeklerin bile gıpta edeceği gür, kalın bir sesi vardır. Vaaz eder gibi şedit bir talâkatla konuşur, dündelik lâkırdıları bile Kuran okur gibi tecvitle 
söyler, her elif onun ă̆zından "dallîn”deki elif miktarı çekilir (Adıvar, 2010/b: 1415)."

Hac1 İlhami Efendi, sadece görünüş olarak değil, savunduğu fikirler bakımından da itici bir din adamıdır. Zira o, başka bir dönemde yaşasaydı muhakkak fikirleriyle halkı galeyana getiren softa olurdu .Zaten, şimdi bile dine bakışı ve dini yorumlayışı son derece zararlıdır. Zira bıçak gibi keskin fikirlere sahip olan Hacı İlhami Efendi, cehennemi dilinden düşürmez. Cehennemin "bilmediği kössesi, ukubetin tarif edemeyeceği şekil yoktur (Adıvar, 2010/b: 15)". Ona göre zevke, cümbüşe düşkün olanlar Cehennem'e giderken; Cenneti'n yolcuları gülmeyen, daima somurtan, oynamayan ve çevresine rahat vermeyen tiplerdir. Hazza ve sevince, hatta hayatın tüm renkli yönlerine karşı bitmez tükenmez bir kin ve nefret duyan bu din adamından herkes korkar. Öyle ki, ondaki bu taassup, Rabia'nın çocukluğunu da cehenneme döndürür ve onun oyuncak bebeğini günah sayıp yakmaya kadar varır. Böylece Rabia, daha beş yaşındayken "Cennet ve Cehennem" kavramlarıyla tanışır ve bu iki kavramdan en çok Cehennem aklında kalır:

"Cehennem onda daha derin alaka uyandırdl. Büyükbabası söylerken dişleri kilitlenir, arkası ürperirdi. Fakat gözlerini açar dinlerdi. Evvelâ İmam, Dante'yi solda sifir bırakacak bir dehşetle bu ukubet diyarını canlandırıyor, sonra babasinın ezelî yurdu orası olduğunu, şüphe götürmez bir katiyetle söylüyordu (Adıvar, 2010/b: 30-31)."

Hac1 İlhami Efendi'ye göre saz sesinden, cümbüşten, türkü ve kahkaha sesinden geçilmeyen Sinekli Bakkal'n tüm sakinleri, gönlünde ahuzarlar, nedametler olmadığı için cehennemliktir. Hatta o, kendisini ziyarete giden Peregrini'ye Rabia'nın bile cehennemlik olduğunu söyler: "Rabia da, sen de, hatta Sinekli Bakkal halkı da hepiniz cehennemlik... Hiçbiriniz Hak dininin ne idüğünü anlamış değilsiniz (Adıvar, 2010/b: 370)."

Modayı bidat sayan, musikîyi günah olduğu için yasaklayan ve şimdiki gençlerin hepsini dinsiz kabul eden Hacı İlhami Efendi'nin hemen her şeyine karşı çıktığı bu hayatta reddedemeyeceği tek şey paradır. Rabia'nın güzel sesine bakıp onu hafız yaparak, mevlitlerde kazandığ 1 parada daima hak iddia eden Hacı İlhami Efendi, Selim Paşa'nın Rabiya'ya özel ders verme isteğine, başta dinî taassubundan gelen endişeyle karşı koysa da parasına zarar gelmeyeceğini öğrendiğinde ses çıkarmaz. Ayrıca, bu teklifi duyan Hacı İlhami Efendi, Paşa'nın evine kapılanmayı bile düşünür. Ondaki bu maddeye bağl1l1k, ölüm döşeğindeyken bile devam eder.

Hacı İlhami Efendinin yaşanılan hayatı reddeden, hoşgörüsüz ve şiddet dolu din anlayışının karşısında, heteredoks bir din anlayışının temsilcisi Vehbi Dede vardır. "Doğu'nun vardlğg en ince, olgun, gerçek din anlaylşına örnek sunulan Vehbi Dede (Moran, 2011: 159)" roman boyunca, gerek yazar gerekse de diğer roman kişileri tarafindan "evliya" bir adam olarak gösterilir. Kâinatı anlayan ve ona seven gözlerle bakan bu Mevlevî dedesi, hayata bir şaka gibi bakarken aynı zamanda tüm insanları kucaklayan bir hoşgörüye de sahiptir. Bu cephesiyle o, dinsiz olan Peregrini'ye, ihtilâlci düşüncelere sahip olan Hilmi Bey ve 
arkadaşlarına, bâtıl inançlara sahip Pembe'ye, Allah'ın serseri çocuklarına benzettiği Tevfik'e ve Rabia'nın eğilimlerine daima anlayış ve tebessümle yaklaşır. Zira, ona göre insanın varlık sebebi sevgidir ve bu insan, bin bir zıtlıktan oluşmuş bir halitaya benzer.

Vehbi Dede'nin temsil ettiği din, aşka dayanır ve bu aşk hiçbir zaman maddeye dayanmaz. Ancak burada şunu belirtmekte fayda vardır: Şeytanla Allah'ı bir görme, ortodoks görüsse uymadığı gibi heterodoks görüşe de tam anlamıyla uymaz. Bu bakımdan Dede'nin görüşünde Halide Edib'in özgün bir din anlayışının yansımasını görürüz:

“...Dede'nin bu düşüncesi, ortodoks İslam öğretisinin dişında kalır. Bu düşüncenin tasavvufun içinde değerlendirilmesi gibi bir sonucu doğurmaz. Bunun Halide Edib'e ait bir fantezi olarak görülmesinde bir sakınca yoktur. Hâl böyle olunca romanıcın idealize ettiği ve toplumsal yapının istikrar kazanmasinda son derece hayati bir rol biçtiği Vehbi Dede'nin, heterodoks İslam öğretisinde ve geleneksel Türk toplum yapısında 'gerçek' bir karşıliğa sahip olduğunu söylemek de kolay olmaz (Yavaş, 2013: 766)."

Vehbi Dede'nin, sahip olduğu din anlayışının bizce en önemli özelliği düşünceye dayanmasıdır. Yazar bunu şöyle ifade eder: “-Peregrini dostum, Tevfik kâğ lt parçalarını yaşatırken, fikrin maddeye ne kadar hâkim olduğunu düşündün mü? Fikir gidince insan da kâğıt gibi cansız, mânâsız oluyor. Bu akşam İsa'nın şu sözlerini hatırladım: "Allah ölülerin değil, dirilerin Allah'ı!... (Adıvar, 2010/b: 125). ” Onun Peregrini'ye söylediği bu sözler, yazarın düşünceye ve yaşayan hayata dönük bir din anlayışını savunduğunu açıkça gösterir.

Vehbi Dede, bir din adamı olarak İslam'ın daima sevgiye ve merhamete dayandığını bilir. Ona göre bu dinde, korkuya yer yoktur:

"Rabia'nın büyükbabası gibi ruhanîler insanoğlunu korkutmak için bu ahtapotu yalancı ilahlar, zebaniler, cinler ve periler klyafetine sokar. Dünyanın başına belâ olan her zalim hükümdar bu bin kollu ahtapotu kullanır. İnsan şeklinde vampir ruhlu münferit katiller, vampire benzeyen kanl fikirler, hep bu ahtapotun kollartyla habasetlerini icra ederler. Bu ejderhayı öldürmeden, insan ırkı için ne sulh vardir ne hürriyet (Adivar, 2010/b: 378)."

Bir Mevlevî şeyhi olan Vehbi Dede'nin ideal bir din adamı olarak okuyucuya sunulması, yazarın Mevlevîliğe yakınlığını da gösterir. Vehbi Dede'nin kişiliği ve din anlayışı, Doğu'nun manevî değerlerinin üstünlüğünü gösterir. Yazar, bunu daha kalın çizgilerle belirtmek için, Batı düşüncesinin içinde yetişen, koyu bir Katolik'ken dinsizliği seçen Peregrini'yi karşımıza çıkarır. Peregrini, felsefe ve tarihe dair pek çok şeyle bilmekle birlikte Şark ilimlerini bilen, Garp'taki fikir hareketlerini sürekli takip eden bir entelektüeldir. Afaroz edilmiş olan bu Katolik, on beş senedir Müslümanlarla iç içe yaşamaktadır. Kendisini "Şeytan'ın zümresinden" biri olarak gören Peregrini, içinden çıktığı Batı dünyasını daima soğuk ve ruhsuz bulur ve bu boşluktan kurtulmak için "şark ikliminde sükûn ve şifa (Adıvar, 2010: 116)" arar. Nitekim o, bu sükûn ve şifayı İslam'da bulmuş gibidir. "Eğer bir din edinmek istesersem mutlak Müslüman olurdum (Adıvar, 2010/b: 
116)" diyen Peregrini, İslam'ın fert anlayışını kendisine daha yakın bulur. Onun bu tavrı, Doğu'nun Batı'ya olan manevî üstünlüğünü göstermesi bakımından dikkate değerdir (Moran, 2011: 173). Bu durum, koyu bir Katolik olan ve annesinin katı tutumları yüzünden dinsizliği seçen Peregrini'nin, Vehbi Dede'den gelen hoşgörülü din anlayışına sahip Rabia ile evlenmesiyle pekiştiririlir.

Kaderci görüşün en iyi örneği Selim Paşa'dır İnsanoğlunu hayatın türlü sıkıntılarından kurtaran bir kaderci anlayışa sahiptir. Bu anlayışın nedeni Vehbi Dede'nin tesiriyle açıklanabilir. Bu tesir Rabia'da da görülür. Bir dinsize gönlünü kaptıran Rabia, "hayatta olan her şeyi, görünmeyen gizli bir kuvvete atfedecek hilkatlerden biriydi (Adıvar, 2010/b: 318)." Bu yaratılışta olan Rabia, Peregreni'nin annesinin ölümü üzerine kaybolmasıyla gönül macerasını Allah'ın bir hikmeti ve sinavi olarak yorumlar:

"Her şeyde bir hikmet vardır, Peregrini'nin anasının ölümü, Rabia'ya gökten indirilen bir alâmet. Tövbe etmesi, istiğfar etmesi gönlünün günahın çıkarıp atması için onu ikaz eden ilahî bir alâmet. Rabia'yı samedaniyet imtihan ediyor. İmanının kudretini, salâbetini deniyor (Adıvar, 2010/b: 318)."

Halide Edib, Handan romanında maddeci bir dünyayı temsil eden Nazım'ın fikirlerine karşılık Selim Bey'in manevî olanı önceleyen müsamahalı din anlayışını savunmuştur. Yazarın bu tutumu Sinekli Bakkal romanında da devam eder. Hilmi Bey ile arkadaşları Galip ve Şevki Bey, pozitivist ve ihtilâlci Genç Türkler'dendir. Dinsizliği sebebiyle Peregrini'ye hayran olan bu gençlerin getirecekleri yeni nizamda dine, daha geniş anlamda manevî kıymetlere yer yoktur. Bu bakımdan Vehbi Dede'yi memleket için Hacı İlhami Efendi'den daha zararlı bulurlar:

"-Bence İmam, bizim memleketimiz için Dede'den daha az zararlıdır. Dervişin felsefesindeki uyuşturucu, uyutucu zehir Imam'ın cennet, cehennem masallarından daha çok tehlikeli. Imam sadece batıl itikatların doğurduğu bir sürü masalı tekrar ediyor, Dede iyilik, kötülük arasındaki farkı kaldırıyor. L̇yiyi fenâyı tablolarında boya diye kullanan sanatkâr bir Allah mefhumu çıkarıyor (Adıvar, 2010/b: 89)."

Sinekli Bakkal'da din meselesi üzerinden ele alacağımız son konu, İslam dininin son Peygamberi'nin doğumunu anlatmasıyla kutsî bir özellik taşıyan "mevlit" törenleridir. Romanda iki farklı mekânda okunan mevlit, yazar tarafından itinalı bir üslupla anlatılmıştır. Yazarın bu tutumu, hem İslamî değerlere önem vermesinden hem de kadın olmasından kaynaklanır. Bu durumu yazarın kadınlığına bağlamamızın dayanağı, Mevlide katılan cemaatin, özellikle mevlidin "doğum" kısmında ağlamaları, hatta kendilerinden geçmeleridir (Adıvar, 2010/b: 51).

\section{Tatarcık (1939): Maddeci Fikirlere Karşı Din}

Tatarcık, Cumhuriyet Dönemi'ndeki sosyal değişimlerin üç nesil üzerinden anlatıldığı bir romandır. Dedeler, babalar ve gençler (Enginün, 2007: 276) olarak sınıflandırabileceğimiz bu üç farklı neslin hayata bakış açıları farklıdır. Bu farklılık elbette "din" alanına da yansımaktadır. Bu bağlamda romanda, nesillerin dine karş1 tutumları yazarın diğer romanlarında olduğu gibi tipler üzerinden anlatılmaktadır. 
Halide Edib, her şeyden önce dinde taassuba karşıdır ve taassubun öfkeli, baskıya dayanan ve başkasına tahamülü olmayan yönlerini daima toplum için zararlı bulur. Nitekim, bu cins mutaassıp kişilerin verdiği dinî eğitim, toplumda sakat bir din anlayışına ve hatta din karşıtı bireylerin yetişmesine sebep olabilir. Bu bağlamda mutaassıp zihniyeti temsil eden bir tip olarak Safa'nın vaktiyle Valide Camii'nde müezzin olan babası Hacı İbrahim Efendi'yi ele almak gerekir. Hac1 İbrahim Efendi, tüm aile bireylerini, bilhassa Safa'y1 "kendince İslâmiyet telakki ettiği birtakım ahkâma göre yaşatmaya çalışmış (Adıvar, 2016/c: 87)” biridir. Ancak onun bu İslam anlayışı çizgileri kesin olan, hata kabul etmeyen bir anlayıştır. Ona göre Müslüman olmayan herkes asılmaya veya işkence edilmeye lâyıktır. Evde kesin oterite olan ve herkesi bu din anlayışına göre terbiye etmek isteyen Hacı İbrahim'in isteklerine ve yasaklarına bir tek karısı uyarken; kızı, babasının yanında eski biçim Müslüman, dışarıda olabildiğince serbesttir. Oğlu Safa ise kendisini idrak ettiği günden beri babasının sert ve anlayışsız tavrına isyan eder (Adıvar, 2016/c: 87). Bu durum, Hacı İbrahim Efendi'nin mutaassıp din anlayışının nasıl ters teptiğini ve, reddedilen bir din anlayışını göstermektedir.

Halide Edib, toplumdaki bâtıl inançları da bazen ironik bazen de ciddi bir üslupla eleştirir. Tatarcık romanında böyle bir durumla karşılarışırız. Buna göre Poyraz köyü sakinleri ıslık çalmaya ve keçiye karşı ön yargılıdır. Bunun sebebi her ikisinin de şeytanla münasebetinin olduğuna inanmalarıdır. Zira Tatarcık'ı keçiyle görenler onun gizli kuvvetlerle bağlantısının olduğunu düşünerek etrafında çeşitli efsanler oluşturmuşlardır (Adıvar, 2016/c: 28).

Tatarcık'ta Feridun Paşa'nın kızı Saide Hanım'ın kocası Miralay Nihat, Tanzimat Dönemin pozitivist ve materyalist insanını temsil eder. Ruhun varlığını ve mistik tavırları reddederek "din tamamen kalkmayınca dünyanın medenileşemeyeceğine (Adıvar, 2016/c: 53)" inanarak dinsizliği kendisine din edinmiştir. "Ona göre dinsizlik dini o kadar etraflı, insanî ve ahlâkî kaideleri haizdir ki; ancak ona mensup olan bir adam aklindan, muhakemesinden gelen bir inzibatla tam adam olabilir (Adıvar, 2016: 54)." Bu bakımdan o, Salim'in "İnkılâpların Psikolojik Amilleri” çalışmasını beğenmez ve Salim gibi eğitimli ve kültürlü bir insanı toplum için zararlı bulur. Aslında onun dinsizliğine sebep insan aklı ve muhakemesinin efsane zincirleri içinde bulunmasındandır. Fakat onun önündeki en önemli engel ilmin son senelerde her şeye cevap verememesiyle çıkmaza girmiş olmasıdır.

Miralay Nihat gibi dinsizliği ile meşhur, fakat Cumhuriyet Dönemi genci olan diğer bir kişi de Safa'dır. O, yazarın "büyük ölçüde kusurlu bir terbiye sonucuna (Enginün, 2007: 279)” bağladığı Marksçı görüşe sahiptir. Babasının baskılarından ötürü dinsizliği seçen, onun abdest suyuna tükürüp seccadesine köpek tersi sürecek kadar öfke dolu olan Safa için "yalnız dindar olanlar değil, din meselesinde lakayt olanlar da insanın en büyük düşmanı, kökleri kazınması lazım gelen, medeniyeti kurutan yabanî muzır otlardır (Adıvar, 2016/c: 87)." Safa'nın Marksizm'i benimsemesinin altında da yine bu ideolojinin dini reddetmesi ve komünistlerin inkılâplarını baskıyla, şiddet ve kanla yapması yöntemleri 
yatmaktadır (Adıvar, 2016/c: 87). Onun komünizme imanı, Miralay Nihat'1 bile ürkütür. Çünkü Miralay Nihat'ın din anlayış1 "19. asrın sakin, liberal, heyecan karışmayan kitaplar arasında esasları tespit edilen bir din (Adlvar, 2016/c: 173)" iken Safa'nın anlayışı "daha karanlık ve azgın bir insiyakın, isyanın, tahakküm arzusunun, cidalin doğurduğu karanlık ve iptidaî bir din (Adıvar, 2016/c: 173)"dir. Özetle o "eli falakall yeni bir softa (Adıvar, 2016/c: 201)" dır.

Din karşıtı kişiler, romanda toplum için zararlı görülürken olumsuz dinî tavırlar içindeki roman kişileri de toplum için zararlı bireyler olarak sunulur. $\mathrm{Bu}$ tiplerin romandaki örnekleri Şinasi ve aile fertleridir. Bu bakımdan Şinasi'nin ailesi, Ramazan'da oruç tutup cemaatle namaz kılarken, noelde de ağaç süsleyip sabaha kadar dans eder (Adıvar, 2016/c: 86)." Şinasi de böyle bir ortamda yetişmiştir. Dinle pek alakası yoktur, ancak o, "İtikatsızlı̆̆ını bir marifetmiş gibi teşhir etmez (Adıvar, 2016/c: 84)" Bu yönleriyle Şinasi, Halide Edib'in yeni toplum düzeninde dine karşı tutumuyla istemediği bir tiptir.

Romanda bu olumsuz, reddedilen tip ve durumlar dışında yazarın olumlu bir üslupla okuyucuya sunarak arzuladığı dinî anlayışı temsil eden tipler, Feridun Paşa ve Gülizar Hanım'dır. Feridun Paşa'nın dine bakışı damadının tamamen aksidir. Her ne kadar dinî itikatları fazla yerine getirmese de dini toplum için elzem bulur ve onun askerlik üzerine düşüncesi bunun göstergesidir: "Paşa Baba'ya göre ordular daima cesarete, manevî itikatlara, bilhassa dinî salabete dayanır (Adıvar, 2016/c: 53).” Paşa'nın dini ordular için elzem olarak kabul etmesi, Millî Mücadele'ye bizzat cephede destek olan Halide Edib'in fikirleriyle örtüşür.

Gülizar Hanım ise eşine karşı vefakâr ve dindar bir kadındır. Paşa'ya Amentü'yü okurkan son derece saygilıdır: "Kalın halının üstüne diz çöktü,başörtüsünü düzeltti, ellerini dizlerinin üstüne koydu, başladı (Adıvar, 2016/c: 187).

\section{Sonsuz Panayır (1946): Yozlaşmış Cemiyetin Din Algısı}

İkinci Dünya Savaş1 (1939-1944) yıllarında İstanbul sosyetesinin bozulmuşluğunu anlatan sosyal bir roman olan Sonsuz Panayır'da yazar, toplumsal yozlaşmanın sebeplerini tespit edip eleştirirken o dönemin "din" algısını da gündeme getirmiştir. Bu bağlamda Halide Edib, bir panayıra benzettiği cemiyette "din" üzerinden farklı meseleleri ve anlayışları roman konusu yapmıştır. Bu bağlamda yazar, yabancı okullar, çocuklara verilen dinî eğitim, yeni neslin dine bakışı ve laiklik gibi meselelere değinmiştir.

Romanın başkişisi Ayşe, Süleyman ve Behire Bolluk çiftinin biri on beş, diğeri on yedi yaşında olan kızları Malike ve Müfide'ye Kuran okuma ve namaz sureleri üzerine din dersi verir. Bu tip zengin ailelerde çocuğa ders verilmesi İngiliz hayranlığından gelen bir modayken Bolluk ailesinde durum farklıdır. Zira, bu iki kız kardeş Dame de Sion mektebine gitmekte ve burada aldıkları eğitimle Hristiyan âdetlerinin tesiri altında yetiştirilmektedir:

"Mamafih Bollukların kendi ă̆ızlarından ögrendiğime göre bunlar ne modadır ne de çocuklar namaz kılsınlar diye öğretiyorlarmış. Babalarına bilhassa annelerine, sörlerin kendi aralarında dualarına, kiliselerine karşı hakiki bir 
heyecan duyduklarını ihsas etmişler, hatta bu koskoca kızlar aralarında kilise duaları bile okumaya başlamışlar. İşte bu Bollukları ürkütmüş, kiliseye karşı cami, Latince duaya karşı Arapça duayı çıkarmakla çocuklarını Hristiyan olmak ihtimalinden uzaklaştırmışlardır (Adıvar, 2016/d: 34)."

Böylece kendisi de bir Hristiyan okulu mezunu olan Halide Edib, yabanc1 okullarda eğitim gören çocukların oralarda verilen eğitimle asimile olabileceğine dikkat çeker. Böyle bir durumun yaşanmaması için çocuklardaki dinî boşluğun mutlaka doldurulması gerektiği fikri roman kişilerinden Ali Bey tarafından ifade edilir (Adıvar, 2016/d: 34).

Burada önemli olan diğer nokta Ayşe'nin temsil ettiği modern gençliğin din dersleri bağlamında "din”e bakışıdır. Zira "Lüzumsuz, bu köhne, para etmeyen, üstelik de insana mürteci damgası vurduran bu şeyleri homurdana homurdana (Adıvar, 2016/d: 34)" babasından öğrenen Ayşe'yi, Bolluk ailesi gibi modern bir ailenin, çocuklarına din eğitimi vermesi korkutur: "Arada bir acaba bu kadın çocuklarını Protestan mı yapacak, diye düşünmedim değil çünkü biz modern gençler, dinin her türlüsünden ürkeriz (Adıvar, 2016/d: 37). ” Ayşe'nin bu sözlerini, Halide Edib'in dönemin Türkiye'sine karşı bir eleştirisi olarak görebiliriz. Çünkü, dönemin Türkiye'sinde laiklik adına dinin toplumsal rolü ve önemi reddedilmiş ve bazı kesimlerde dinsizlik, modernliğin gereklerinden kabul edilerek herhangi dinî bir eylem veya söylem, gericiliğin göstergesi olarak yorumlanmıştır.

\section{Döner Ayna (1953): Olumsuz Dinî Tavırların Romanı}

Döner Ayna, "bilhassa Cumhuriyet'ten sonra, hürriyet, demokrasi, kadın hakları gibi konuların, ahlâksız ayaktakımı arasında nasıl telakki edildiğini yer yer ortaya koymuş (Enginün, 2007: 302)" olmasıyla yazarın topluma olumsuz bir bakış açısıyla yaklaştığı romanıdır. Yazarın diğer romanlarından ayrılan bu eserde, roman kişilerinin kendi menfaatlerine göre dine yaklaştıkları görülmektedir. Bu yönüyle Halide Edib din meselesinde olumsuz tipler üzerinden giderek olması gerekeni ifade eder.

Romanda ilk olumsuz örnek Hanife'nin babası Hacı Murat'tır. Bu kinin kendi menfaatlerine göre yorumladığ 1 dinde kadının yeri sadece cinsel bir obje olmaktan ibarettir. Bu bakımdan içtiği rakının Kur'an-1 Kerim'de erkeklere haram, kadına yasak olduğunu söyler: "Hasan, Kuranı Kerim'de rakının haram olduğuna işaret eden ayet yoktur. Sadece sarhoşken ibadet etmememizi emreder. Ĕger kafamıza vurmadan rakı içersek hiç de haram değildir. Amma velakin kadınlar için öyle değil ha! Saçı uzun aklı kısa mahlukata sadece su gerektir (Adıvar, 2015: 46)." $\mathrm{Bu}$ sözler dini keyfine göre yorumlayan insanın ifadeleridir.

Hac1 Murat'ın dinden beslenerek nüfuz sahibi olmasında en büyük etken, köylünün cahil olmasıdır. Bunu bilen Hacı Murat, oğlu Hasan'ın hasta bir ineği iyileştirmesini kendi kerametine bağlayarak nüfuzunu arttırmak ister: "Hacı Murat kendisine, Hasan'ın bir hasta ineği iyi ettĭgi söylenirken, başını esrarengiz bir tavirla salliyor, bu hayvanlara şifa verme kudretinin Hact Murat'ın dualarindan, görünmeyen kuvvetlere hâkim olmasından ileri geldiğini ihsas ediyordu (Adıvar, 2015: 66)." 
Halide Edib, dinsizliği modernlik olarak telakki eden insanları da daima romanlarında eleştirmiştir. Döner Ayna'da bu tipi Mürsel temsil eder. Her bakımdan kötü, sadist, ahlâksız ve çıkarcı bir tip olan Mürsel, kanunları ve modernlik kavramını kendi emellerine göre yorumlar. Ona göre "din bilhassa Allah adinı anmak moderenliğe mugayir ve en köhne hareketti (Adıvar, 2015: 154)."

Döner Ayna romanında şeriat yanlısı olarak "dine karşı olanların katli helaldir (Adivar, 2015: 197)" diyen softa hocaefendi ile pozitivist bir ihtilalci olarak dinsizliği savunan ve Hocaefendi gibilerin dini tepelediğini düşünen Bilal de eleştirilen tiplerdendir. Romanda bu iki tip Demirbaş'in şu sözleriyle eleştirilir: “... hocaefendi dini bir uğruna, Bilal de dinsizlik uğruna bir katiller serisi yaratmak istiyor... (Adıvar, 2015: 198)" Bu sözler, Halide Edib'in sert ve keskin uçları olan dinden taraf olmadığını gösterdiği gibi dinsizliği savunan görüşlere de karşı olduğunu gösterir.

Son olarak, romanda çektiği sıkıntılara kadercilik anlayışından gelen bir güçle sabreden Hanife'nin temsil ettiği din anlayışının da yazar tarafından eleştirildiğini söyleyebiliriz. Zira, Demirbaşların evinde kendisini eğitim yönünden geliştiren Hanife, okumayı öğrenir. Ancak sadece dinî mevzuları okuyan, namazını kaçırmayıp orucunu tutan Hanife'ye bunların hiçbiri ahlâk bakımından tesir etmez. "Tipkl Hacl Murat gibi bunlar, herhangi bir habasetin kefareti olarak (Adivar, 2015: 209)" görülür. Halide Edib, bu şekilde ahlâkla bütünlük arz etmeyen bir ibadeti ve din anlayışını da eleştirmiş olur.

\section{Âkile Hanım Sokă̆ı (1957): Makineleşen Dünyada Bireyin Dinde Kendini Bulması}

Sosyal hayatımızda görülen değişimlerin eski-yeni zemininde ele alındığı Âkile Hanım Sokağı romanında Halide Edib, din meselesine de bu açıdan bakar. Bu bağlamda romanın ikinci kısmındaki "Dün ve Bugün” bölümünde yazarın ele aldığı iki farklı konu vardır: İronik bir dille eleştidiği dindar adam tipi ve makineşelen dünyada insanların bir alternatif olarak yöneldiği din.

Romanda yazar tarafindan ironik bir dille eleştirilen ve reddedilen bir tip olan roman kişisi, daima pamuklu bir hırka giydiği için "Hırka-i Şerif" lâkabı takılan ihtiyardır. Buna göre İhtiyar, müstehcen mevzulara girmediği sürece hoşsohbet birisidir ve dinden pek bahsetmese de sevmediklerine sürekli zındık der. Bugünün her şeyini eleştirirken mazi için "rezaili bile eltaftı (Adıvar, 2017/c: 117)" diyerek romanda eskiyi temsil eden bu ihtiyar, toplumda yeni görülen "rock and roll" dansını kalçalarını ve kafasını sallayarak "Allah Allah" zikirleriyle bir Rüfaî ayinine benzetip bir cezbe hâli yaşar (Adıvar, 2017/c: 123).

Halide Edib'in üzerinde durduğu ikinci mesele ise, matematik profesörü ile iktisat prefösörü üzerinden okuyucuya aktarılır. Buna göre, Neriman'ın eniştesinin evinde karşılaşan bu iki profesör arasında makine medeniyeti üzerine bir tartışma başlar. $\mathrm{Bu}$ tartı̧̧mada matematik profesörü, makineleşen dünyada "insaniyete yeni bir veçhe vermek (Adıvar, 2017/c: 121)" gerektiğini söyleyerek yeni bir felsefe arayışında olduğunu beyan eder. İktisat Profesör'ü, pozitif bilimle uğraşan Matematik Prefösör'ünün bu görüşlerine şaşırır. Çünkü ona göre "bugünkü 
medeniyetin temeli tamamen iktisat üzerine (Adıvar, 2010/c: 121)" kuruludur. Matematik Profesör'ü bu görüşü reddeder. Zira, bu makine medeniyetinde insanların hepsi hayvana benzemektedir ve hepsinin içi bomboştur. Bu kötü gidişte insan tekrar kendi kendini bulmalıdır. Amerika'da bunun için insanlar dine yönelmektedir ve bizim kapattığımız tarikatlarin hepsi orada açılacaktır (Adıvar, 2010/c: 122).

\section{Sevda Sokağı Komedyası (1959): Dün ve Bugün Arasında Toplumsal Yapı}

Sevda Sokağı Komedyası, Abdülhamit Dönemi'nden Cumhuriyet'e kadar uzanan bir zaman dilimi içerisinde, köylü Emine'nin saplantıya dönüşen kentli insan olma arzusunu anlatır. Bu bağlamda toplumsal değişimle birlikte köylü ve kentli insan tipinin sorgulandığ bu romanda din, iki farklı yer ve zamanda karşımıza çıkar:

İlk olarak din, Osmanlı konağında verilen bir terbiye olarak karşımıza çıkar. Buna göre, sarayda kilercibaşı olan Hamdullah Bey'in eşi Sabiha Hanım, bir kazasker kızıdır. Eski usulde terbiye görmüş, kültürlü ve etrafına daima iyilik etmekten hoşlanan bu kadının en sevdiği şey, küçük beslemeler alıp onları iyi terbiye etmek ve evlendirmektir. Bu bakımdan onun konağındaki beslemelere musiki eğitimin yanı sıra dinî terbiye de verilir. Bunun için konağa, beslemelerin karşısında daima başlarını örtüp sessiz ve saygılı bir şekilde beklediği Hoca Efendi gelir. Beslemelerin tavrı, Kuran'a gösterdikleri saygıdan ötürüdür: "Bu, hocadan kaçmaktan ziyade, dersleri Kur'an okumak olduğu içindi (Adıvar, 2011: 32). Hamdullah Bey'in konağındaki bu terbiye şekli Halide Edib tarafından mazimizin güzelliği olarak okuyucuya sunulmuştur.

İkinci olarak din, Cumhuriyet Dönemi'inde kadının toplum hayatındaki rolüyle birlikte karşımıza çıkar. Emine, İstanbullu bir hanımefendi olmak için ilk hedefi olan Macit'le evlenir. Hanımefendiliğin bir göstergesi olarak Macit'le birlikte kadınlı erkekli, sazlı sözlü meclislere katılır. Bunu duyan edebiyat öğretmeni Turhan Bey Macit'e "kadınlar da çakıştırıyorsa, bu Müslüman kadınları için biraz acayip değil mi? (Adıvar, 2011: 132)" diye sorar. Böylece Halide Edib, daha önceki romanlarında da gördüğümüz gibi kadını erkeğe göre daha çok sınırlayan bu dinî anlayışa karşı eleştirel bir tavır takınmıştır.

\section{SONUÇ}

Görüldüğü gibi Halide Edib romanlarını kurgularken iki yol seçmiştir: Birincisi konusuna yaklaşırken ele aldığı olumlu ve olumsuz tiplerin mukayesesi yoluyla olumluyu öncelemek, ikincisi ise olması gerekeni veya olumluyu önermek için olumsuz tipler kurgulamaktır. Böylece Yarattığı tipler üzerinden toplumsal meseleleri irdeleyip fikirlerini okuyucuya aktaran Halide Edib'in romanlarında din, Türk toplumunun vazgeçilmez bir değer kaynağı olarak sunulmuştur. Nitekim romanlardaki ideal tiplerin her zaman millî değerleri bilen, yozlaşmaya ve taklitçiliğe karşı eleştirel bir tutum takınan ve "mutlaka dindar, hiç değilse dinî 
hislere saygılı (Enginün, 2007: 32)" kişiler oldukları açıkça görülmektedir. Yani okuyucunun, ilk olarak "Raik'in Annesi”"nde karşıllaştığ “din" öğesi, yazarın diğer romanlarında da görülen köksüzlüğe, taklitçiliğe ve yozlaşmaya karşı millî kimliği oluşturan, asıl kaynağa dönüşte vazgeçilmeyecek temel unsurlardan biri olarak ele alınmıştır. Bunlara ilave olarak Cumhuriyet Dönemi'nde yazdığı romanlarında ise din, laik anlayışa uygun, maddeci, marksist ve ihtilâlci anlayışlar ve modalar karşısında savunulan bir değer olarak yorumlamıştır.

Böylece Halide Edib'in incelenen romanlarında din anlayışının şöyle bir özelliği ortaya çıkmaktadır: Öncelikle din sosyal yapı, millî kültür ve bireyin iç dünyası için vaz geçilmez bir değerdir. Bunun için yazar, kişilerin dinî hayatını kurgularken din meselesine öncelikle millî eğitim, millî kültür, bireyin iç dünyası, toplumsal kimliği muhafaza gibi açılardan konuyu ele almıştır. Yazar, bu bağlamda din meselesine, yaşadığı dönemin değişen koşullarına göre bir yorum da getirmiştir. Böylece yazar, romanlarında dini hayatının çeşitli görünümlerini ayrıntısıyla ele alma ihtiyacı duymuş ve toplum hayatının önemli bir değeri olarak gördüğü dine farklı açılardan çeşitli yorumlar getirmiştir.

Ancak, Halide Edib'in romanlarında önemli bir yer işgal eden din, "resmî / ortodoks" anlayıştan öte "heterodoks" anlayışa yakın duran, yazarın özgün bir tutumla ele aldığı bir değerdir. Tüm insanları kucaklayan bir hoşgörüye sahip olan bu anlayışın temel özelliği ise laik anlayışa uygun olmasıdır. Nitekim Halide Edib, devletin din konusundaki tutumunu irdelerken "devletin dine müdahale ettiği ya da dinin kamusal alanın dişına çıkarılıp bireysel hayata 'hapsedilmesi' şeklinde formüle edilen bir tarzı (Yavaş, 2013: 754)" reddeder. Sinekli Bakkal romanı bu görüşümüzün en iyi örneğini oluşturmasıyla önemlidir. Bu görüşe uygun olarak Berna Moran'ın Sinekli Bakkal romanı üzerine yaptığı tespiti aktarmak doğru olacaktır:

"Adlvar, din derken, teokratik bir devletin resmî dini olarak Müslümanlığ kastetmiyor. Ulemanın anladiğı anlamda kurallara dayalı dini değil, Osmanlı İmparatorluğu'nda bu resmî dinin yanı sira tarikatlarda gelişmiş olan tasavvufu kastediyor. Daha doğrusu, Mevleviliğin aşka ve hoşgörüye dayall, halk sinıfina bir çeşit bilgelik kazandiran mistik dünya görüşü (Moran, 2011: 179).”

$\mathrm{Bu}$ görüş Halide Edib'in romanlarında sunduğu din anlayışının tamamını ifade etmese de özetler mahiyettedir.

İncelenen eserlerden bilhassa Handan, Vurun Kahpeye ve Sinekli Bakkal romanlarında daha belirgin olarak "heterodoks" bir din anlayışı ortaya konulduğu açıkça görülmektedir. Hatta bu din anlayışının "deizm"e yakın duran bir tarafı olduğunu da söylemek mümkündür. Zira, yazarın romanlarındaki ideal tipler, dini akı1 öncülügünde değerlendirmektedirler. Onların, dinin hoşgörülü, herkesi kucaklayan bir yapıda olması gerektiğine akıl yoluyla ulaşması ve akla dayanan bir dine/İslam'a yönelmeleri bu iddiamızı güçlendirmektedir. 


\section{KAYNAKÇA}

ADIVAR, Halide Edib (1973/a), Seviye Talip, Atlas Kitabevi, İstanbul. ADIVAR, Halide Edib (1973/b), Yeni Turan, Atlas Kitabevi, İstanbul. ADIVAR, Halide Edib (1982), Raik'in Annesi, Atlas Kitabevi, İstanbul. ADIVAR, Halide Edib (2010/a), Zeyno'nun Oğlu, Can Yayınları, İstanbul. ADIVAR, Halide Edib (2010/b), Sinekli Bakkal, Can Yayınları, İstanbul. İstanbul.

ADIVAR, Halide Edib (2011), Sevda Sokağı Komedyası, Can Yayınları,

ADIVAR, Halide Edib (2015), Döner Ayna, Can Yayınları, İstanbul.

ADIVAR, Halide Edib (2016/a), Son Eseri, Can Yayınları, İstanbul.

ADIVAR, Halide Edib (2016/b), Kalp A ̈grısı, Can Yayınları, İstanbul.

ADIVAR, Halide Edib (2016/c), Tatarcık, Can Yayınları, İstanbul.

ADIVAR, Halide Edib (2016/d), Sonsuz Panayır, Can Yayınları, İstanbul.

ADIVAR, Halide Edib (2017/a), Handan, Can Yayınları, İstanbul.

ADIVAR, Halide Edib (2017/b), Vurun Kahpeye, Can Yayınları, İstanbul. İstanbul.

ADIVAR, Halide Edib (2017/c), Âkile Hanım Sokă̆g, Can Yayınları,

AYTEMIZ, Beyhan Uygun, (2015), "Fitne ve Feda: Vurun Kahpeye'de Din ve Milliyetçilik", Edebiyat Eleştirisi Dergisi, s. 168-190.

BEYATLI, Yahya Kemal. (2006). Siyasî ve Edeb̂̂ Portreler, Yapı Kredi Yayınları, İstanbul.

ENGINÜ̈N, İnci (2007), Halide Edib Adlvar'ın Eserlerinde Doğu ve Batı Meselesi, Dergâh Yayınları, İstanbul.

MORAN, Berna (2011), Türk Romanına Eleştirel Bir Bakış 1 Ahmet Mithat'tan A. Hamdi Tanpınar'a, İletişim Yayınları, İstanbul.

ÖNERTOY, Olcay (2011), Halide Edib Adivar'ın Romanlarında Toplumsal Eleştiri, Ankara Üniversitesi Dil ve Tarih-Coğrafya Fakültesi Türkoloji Dergisi, C. 18-S. 1, s. 37-46.

YAVAŞ, Gürkan (2013), "Eleştiri ile İdeal Arasında: Halide Edib'in Sinekli Bakkal Romanında 'Din Adamı' Kavramı Etrafında Bir Tartışma", II. Türkiye Lisansüstü Çalışmalar Kongresi Bildiriler Kitabı, II. Türkiye Lisansüstü Çalışmalar Kongresi, 6-7-8 Mayıs, C. III, İstanbul, s. 753-767. 